\title{
Emerging Infectious Diseases in Water Buffalo - An Economic and Public Health Concern
}

\author{
Marvin A. Villanueva, Claro N. Mingala, \\ Gabriel Alexis S. Tubalinal, Paula Blanca V. Gaban, \\ Chie Nakajima and Yasuhiko Suzuki
}

Additional information is available at the end of the chapter

http://dx.doi.org/10.5772/intechopen.73395

\begin{abstract}
Water buffalo is an indispensable livestock in Asia and other countries due to its high meat and milk quality, aside from draft power source. It adapts well to tropical climate and has significant contribution to the livestock industry, provided with improved breeding and good animal husbandry practices. Infectious diseases are hindrance to good reproductive performance of livestock, resulting in huge economic loss. In addition, most of these diseases are zoonotic, posing serious threats on human health. However, its degree of severity varies in each region and is often overlooked. This chapter reviews the common and current updates on emerging bacterial, viral, protozoal, fungal and endoparasitic pathogens that infect water buffaloes worldwide. All of the diseases directly affect the animals' health condition except for schistosomiasis where water buffalo played an important role as shedder of infection to humans. Leptospirosis, brucellosis, Bovine Tb, BVDV and fasciolosis have projected economic impact to water buffalo industry as well as its effect as zoonoses. However, the data seem underquantified since most are neglected diseases and are highly prevalent in developing countries. Further studies are needed particularly in countries where water buffalo is the major livestock than cattle to fully utilize the potential of the animal.
\end{abstract}

Keywords: emerging infectious diseases, economy, public health, water buffalo, zoonosis

\section{Introduction}

Livestock play an important role in the rural livelihood and economy of developing and several developed countries. They are providers of nourishment for billions of rural and urban households as well as income and employment for producers and others working in simple 
and sometimes complex value chains. Large ruminants, especially domestic water buffalo (Bubalus bubalis) are an important livestock species worldwide as it is a source of high quality milk and meat, leather and traction power, in addition to being able to survive on marginal land and subsist on low-quality forages, a good alternative for the breeding livestock especially in tropical countries [1-3]. Water buffalo is known for its rusticity and great adaptability to different topographies, soils and climatic factors. However, they can still be afflicted with various infectious diseases that greatly affect their production performance.

Wild as well as domestic water buffalo population is mainly confined to their breeding sites at 28 countries in Asia, Africa and South America, located in tropical and subtropical areas. A total of 161 million or about $97 \%$ of the 166 million water buffalo population are found in Asian countries; while the African region comprises of 2.12\%, the South American and European region comprises of 0.84 and $0.15 \%$ of the world buffalo population, respectively [4].

The water buffalo were domesticated in Indian subcontinent about 5000 years ago (river buffalo) and in China about 4000 years ago (swamp buffalo) [5]. With around 170 million domestic water buffalo that exists worldwide, more people depend on this gentle beast than on any other domestic animal.

The contact between water buffaloes and cattle or other domestic and wild animals, as well as their access to different ecosystems, has exposed the species to different infectious diseases [2, 6]. These emerging infectious diseases can be caused by bacterial, viral, fungal, protozoal and endoparasites that have a significant economic impact especially in countries or regions where water buffalo served as the major livestock. However, published water buffalo-specific research is limited because it is not an important animal in many countries that have the necessary resources and it is believed that this animals show similar disease manifestation with that of cattle [7].

Several of these water buffalo diseases are endemic in developed and developing countries worldwide. However, epidemiology of these diseases is not fully studied in domesticated water buffalo [81, 82]. Most information on ruminant diseases studied cattle and African wild buffaloes [108]. In addition, livestock importation and exportation is a very important pathway of disease dissemination from one continent to parts of the world [170, 175]. However, still few diseases of water buffaloes are absent in the New World (bovine ephemeral fever) [141] and Australia (trypanosomiasis) [170, 175].

Advancement of the beef and dairy cattle industry has enhanced dispersal of ruminant diseases from endemic parts of Africa, Australia and Southern Asia to the world as observed with bovine ephemeral fever [134, 140], trypanosomiasis [170, 175] and neosporosis [195]. Through these advancements in cattle industry, trypanosomiasis spread out from the tse-tese belt of Africa to the world triggering Trypanosoma spp. to have a wider host range that have a varying pathogenicity depending on the immune system and geography of the host [170].

In some cases, spread of ruminant disease is through vectors or reservoir. For example, bovine ephemeral fever is transmitted from one animal to another via mosquitoes [142], and biting flies transmit trypanosomiasis [168]. On the other hand, multi-species bacterial diseases like leptospirosis and brucellosis are known to be transferred via infected urine of rodents, carnivores $[8,9]$ and other farm animals and infected tissues (placenta, aborted fetuses, etc.) of 
aborted animals [2, 56, 57]. In cases of parasitic diseases, snails act as intermediate hosts for fasciolosis [284] and schistosomiasis [298, 299].

The wallowing behavior or submergence to muddy water predisposes the water buffaloes to different diseases like leptospirosis [8, 9], brucellosis [83], fasciolosis [285], and schistosomiasis [295, 298, 299]. In addition, co-mingling with other buffaloes, ruminants and other animals further facilitate the transmission of these diseases. For example, co-mingling of water buffaloes in wallows increases the transfer rate of brucellosis [83] and schistosomiasis [295, 298, 299]. In some cases, water buffaloes acts as the reservoir or "spill-over" host for some diseases like in tuberculosis $[94,95]$.

Extensive distribution of ruminant diseases have a drastic negative economic impact due to low production output and high animal mortality, threat to public health and international trade and tourism [94]. Deg Nala, an emerging disease of water buffalo often misdiagnosed as foot and mouth disease or mange infection [272], affects milk yield and quality due to infection or necrosis of udder and inguinal canal [271] resulting in lower income to farmers.

Water buffalo also acts as reservoir host for zoonotic diseases like schistosomiasis [295, 298, 299], rotaviral infection [155], leptospirosis [8], brucellosis [84] and tuberculosis [94, 95]. For instance, schistosomiasis, the most prevalent zoonotic parasitic disease globally, infects more than 200 million people in more than 76 countries. With this, \$ 25 million disability-adjusted life years are lost $[298,299]$.

Control of ruminant diseases is often difficult because the causative agents of certain diseases survive in the environment for months and resistant to most disinfectants like in cases of rotaviral infection [152]. In cases of cryptosporidiosis, high prevalence of the disease is due to contamination of oocyst in the environment from great oocyst shedding in feces and survival of oocyst for few weeks to months [227, 228]. Schistosomiasis and fasciolosis are difficult to control due to non-conformity to habitual good and proper husbandry practices, continuous transmission from shedder animals, quantity of intermediate and final host, malpractices of irrigation systems and poor hygiene management [245, 297, 299].

In this review, the overview of each disease, its distribution, epidemiology, transmission, pathogenesis, diagnosis, treatment and control were discussed in order to fully understand the behavior of such diseases which will be beneficial for veterinarians and other health professionals in the control of diseases.

\section{Emerging infectious diseases}

\subsection{Bacterial}

\subsubsection{Bovine leptospirosis}

Leptospirosis in large ruminants has a worldwide occurrence (Table 1). However, majority of the information on this disease is focused on cattle, while it is limited in water buffalo, indicating that both species resemble similar clinical manifestation of the disease [8,9]. 
Bovine leptospirosis is caused by pathogenic Leptospira spp. which involves the serovar Hardjo maintained by cattle, and has an almost global distribution. Leptospira borgpetersenii serovar Hardjo (Hardjobovis, HB) is the common strain of this serovar maintained by cattle, however L. interrogans serovar Hardjo (Hardjoprajitno, HP) also occurs in some parts of the world. Chronic infection is more common due to these serovars which can result in important economic losses due to reproductive wastage $[8,10]$.

Meanwhile, a wide variety of other serovars belonging to the Icterohaemorrhagiae, Canicola, Hebdomadis, Sejroe, Pyrogenes, Autumnalis, Australis, Javanica, Tarassovi and Grippotyphosa serogroups have been reported as causing incidental infections in cattle and water buffalo causing severe disease. Clinical signs include pyrexia, hemolytic anemia, hemoglobinuria, jaundice, occasionally meningitis and death. In lactating cows, incidental infections are often associated with small quantities of blood-tinged milk. The acute phase of clinical disease in serovar Hardjo (both subtypes) infection is usually subclinical, with the exception of lactating cows, where agalactia may occur. Large outbreaks, while very dramatic, are rare and individual cases (even herd outbreaks) can go unobserved unless milk production is recorded [11] (Table 1).

In cattle, the most vital economic aspects of chronic leptospirosis are premature birth, stillbirth, birth of immuno-compromised calves and abortion. In cases of Hardjo infection, the disease accumulates 6-12 weeks after an acute infection. On the other hand, it only takes 4-6 weeks after an acute disease in some cases [26]. Placental infection may also affect the weight of calves; stillborn or weak calves with Hardjo-infected placentas were significantly lighter than uninfected controls. There has also been an association with retention of fetal membranes [26]. Leptospires have been detected for up to 8 days in post abortion/calving vaginal discharges [27]. Infertility, which responds to antibiotic and/or vaccination, is described in Hardjo infection [28].

Infection most frequently occurs through the mucous membranes of the eye, mouth, nose or genital tract. A period of bacteremia which coincides with acute clinical disease can last for a week from the first day of infection. In this bacteremic phase, the organisms can be isolated from most organs of the body most especially in the blood and cerebrospinal fluid. However, after 10-14 days, this phase ends with the presence of circulating antibodies. Peak titers vary considerably (1000-100,000 in the MAT), and these may be maintained for up to 6 weeks, depending on the species, after which a subsequent gradual decline occurs. A secondary bacteremic period (after 15-26 days) has rarely been reported. Low titers may be detectable for several years in many animals [29]. During leptospiremia, leptospires multiply in the proximal renal tubules and are excreted in the urine [8].

Infection on pregnant females often leads to abortion and other neonatal diseases that can be caused by intrauterine infections during the last trimester of gestation. In the event of immunocompetence development, antibodies against the leptospires can be observed in the fetus $[8,30]$.

In host-maintained infection, the persistence of leptospires in the oviduct and uterus of nonpregnant females and in the genital tracts of males were observed [31-34]. In vitro studies 


\begin{tabular}{llll}
\hline Locality & Prevalence (\%) & Technique & Authors \\
\hline New Zealand & $5.7^{3}$ & Serology & Dorjee et al. [12] \\
Mexico & 10.33 & MAT & Leon et al. [13] \\
Sri Lanka & 20.3 & Serology & Gamage et al. [14] \\
Thailand & 21.5 & MAT & Suepaul et al. [15] \\
Nigeria & 3.5 & ELISA & Ngbede et al. [16] \\
Uganda & $42.39^{1}$ and $29.35^{2}$ & ELISA & Atherstone et al. [17] \\
Poland & 3.2 & DAS-ELISA & Rypula et al. [18] \\
Brazil & 32 & MAT & de Carvalho et al. [19] \\
Morocco & 9.09 & Serology & Lucchese et al. [20] \\
Thailand & 19.80 & LAMP & Suwancharoen et al. [21] \\
Philippines & 16.1 & nPCR & Villanueva et al. [22] \\
Nicaragua & 30.31 and 15.38 & MAT and in vitro culture & Flores et al. [23] \\
Brazil (Santa Catarina State) & $6.44^{2}$ & MAT & Favero et al. [9] \\
Northeastern Brazil & $42.9\left(50.5^{2}, 40.5^{3}, 34.6^{4}\right)$ & MAT & Campos et al. [24] \\
Lao PDR & $3.3^{1}$ & ELISA & Olmo et al. [25] \\
& $22.2^{2}$ & & \\
\hline
\end{tabular}

\section{${ }^{1}$ Buffalo.}

${ }^{2}$ Cattle.

${ }^{3}$ Sheep.

${ }^{4}$ Goat.

MAT, microscopic agglutination test; ELISA, enzyme-linked immunosorbent assay; LAMP, loop-mediated isothermal amplification.

Table 1. Ruminant leptospirosis prevalence studies conducted worldwide.

have also shown that leptospires have the ability to adhere to and penetrate the zona pellucida and enter embryonic cells [30]. Chronic persistence in the mammary gland and its drainage to lymph nodes has also been reported [35]. Symptomless infection is thought to be very common as evidenced by the wide disparity between seroprevalence and apparent disease prevalence.

The primary lesion due to this disease damages the endothelial cells of small blood vessels. The severity of disease varies with the infecting serovar, animal species, age, and the stage of infection $[8,30]$. In acute fatal infection, there are no pathognomonic gross changes, but the following can be observed: icterus and the presence of ecchymotic and petechial hemorrhages on the serosal surface of major organs including the lungs, kidney, abomasum and the peritoneum, and pleura and blood in the bladder. Liver may be enlarged with accentuation of the hepatic lobes. Hepatocellular dissociation, intracanalicular cholestasis, hepatocellular necrosis, and Kupffer 
cell hypertrophy may be found on histological examination. Acute interstitial nephritis, with tubular and glomerular degeneration, and the infiltration of mononuclear cells, lymphocytes, plasma cells, and macrophages, may be seen on histological examination [8]. Lesions consisting of scattered gray foci which are usually bordered by a ring of hyperemia are concentrated in the kidneys in the case of chronic leptospirosis. [36].

Fetal pathology varies considerably and depends on the species, the stage of gestation at which infection occurred, and the infecting serovar. Pathological examination of fetuses usually reveals only non-specific findings in cattle. In experimental fetal disease, vasculitis with perivascular hemorrhage predominantly in the liver and sometimes in the lungs and meninges with minor tubular necrosis and interstitial nephritis occurs [37]. These were consistent with what is seen in acute leptospirosis in young animals. Placentitis was also a feature [38].

A definitive diagnosis of leptospirosis is required in the confirmation of leptospirosis as a cause of clinical disease, assessment of the infection and/or the immune status of a herd for the purposes of a control or eradication program on either a herd or national basis, epidemiological studies and assessment of the infectivity status of an individual animal to assess its suitability for international trade or for introduction into an uninfected herd [8].

Laboratory diagnostic procedures for leptospirosis fall into two groups: (1) tests for the demonstration of leptospires and (2) tests for antibody detection. Demonstration of leptospires is usually performed in initial bacteremic phase, untreated fatal cases and aborted or stillborn fetuses and the localization phase where leptospires resides at its organ predilection sites of an infected animal. The available methods for the demonstration of leptospires include direct visualization of organisms by dark-field microscopy [39,40], culture, DNA detection methods [41, 42] and staining (silver and immunochemical) [42-44].

Detection of the organism can be hasten through urine collection upon treatment [45]. Urine samples should be mixed immediately with an equal volume of phosphate buffered saline containing $1 \%$ bovine serum albumin on collection [46].

In the tests for antibody detection, serological testing is the mainly used method of diagnosis such as ELISA, while microscopic agglutination test (MAT) is the standard serological test. The MAT is used primarily as a herd test. It is labor and resource demanding and its sensitivity depends on the stage of infection in individual animal [8].

The treatment of acute leptospirosis in individual animals or in herds is dependent on the use of antibiotics plus supportive symptomatic treatment. When treating herd problems, vaccination may be combined with antibiotic treatment to obviate chronic reproductive wastage [8].

A combination of penicillin and streptomycin has been the antibiotic therapy of choice for the treatment of acute leptospirosis, but ampicillin, amoxicillin, tetracyclines, tulathromycin and third generation cephalosporins have also been used [47-50].

Antibiotics are utilized for the medication about incessant renal also genital leptospirosis, a critical part from control projects. Streptomycin at $25 \mathrm{mg} / \mathrm{kg}$ has been the most widely 
used over vast majority of utilized antimicrobials for the medication of renal carrier animals, although some experiments found to be not powerful [27, 51].

The principles of control are based on the interruption of direct and indirect transmission of infection as well as the reduction of its zoonotic risk. Control strategies must take into consideration the location, number of animals, infecting serovars, maintenance hosts, means of transmission, risk factors and the control options available. Good surveillance information is required. The tools for control include vaccination, antibiotic therapy, assessment of herd/population status (profiling), identification and removal of infected animals, rodent control, reducing risk factors through management systems and permutations of all these methods [8].

Studies have showed that monovalent and bivalent vaccines of serovar Hardjo and Pomona have conferred protection for a year [52]. Multivalent vaccines for cattle compared very unfavorably with monovalent product in a series of experiments [53] but they continue to be sold and the debate about their efficacy continues $[48,54,55]$.

\subsubsection{Brucellosis}

Brucellosis in water buffalo is acknowledged as a contagious infectious disease caused by Brucella abortus, a Gram-negative, non-motile, non-spore forming, aerobic, facultative intracellular coccobacillary bacterium $[2,56,57]$. This bacterium is capable of invading epithelial cells, placental trophoblasts, dendritic cells and macrophages. Reports have found that B. abortus biovars 1-6 and 9 were primarily isolated from cattle and buffaloes [57]. In particular, B. abortus biovar 1 is the most prevalent biovar in countries where bovine brucellosis is endemic [1].

Brucella infections in livestock species represent an enormous economic impact particularly in developing countries due to reproductive problems, reduced milk production and restrictions on animal movements and trade. It is characterized by abortion, predominantly in the last trimester of gestation, premature births followed by retention of placenta, metritis, non-viable calves, infertility, reduction of milk production and lameness as common sequelae to infection in dairy animals while epididymitis and orchitis in bulls [13, 191, 236] (Table 2).

This disease of water buffalo has been reported and considered endemic in many developing (Table 2). In addition, developed countries in Latin America, Southern Europe, Africa, South and Southeast Asia, and the Middle East, especially in the rural areas, where livestock rearing and production of dairy products and by-products is crucial for family income $[2,7$, 56, 75-80].

The epidemiology of Brucella infection has not been studied extensively in domestic water buffalo. These animals shed viable brucella in milk, but dam-to-calf transmission has not been evaluated directly. Infected water buffalo expel the bacterium during abortion, and this may serve as a source of infection for herdmates. Experimental studies have 


\begin{tabular}{|c|c|c|c|}
\hline Locality & Prevalence $(\%)$ & Technique & Authors \\
\hline Sudan & 2.15 and 3.4 & RBPT & Gumaa et al. [58] \\
\hline Malaysia & $0.91^{4}$ & Serology & Bamaiyi et al. [59] \\
\hline Turkey & $6.86^{\mathrm{a}}$ and $6.25^{\mathrm{f}}$ & RBPT and STAT & Aslan et al. [60] \\
\hline Argentina & 1.8 & BPAT & Aznar et al. [61] \\
\hline Ethiopia & $1.9^{2}$ & RBPT & Sintayehu et al. [62] \\
\hline Egpyt & 20 & RBPT and CFT & Hegazy et al. [63] \\
\hline Tajikistan & 6.7 & Indirect ELISA & Rajala et al. [64] \\
\hline Argentina & $2^{3,4}$ & BPAT and CFT & Draghi et al. [65] \\
\hline Morocco & 33.48 & ELISA & Lucchese et al. [20] \\
\hline Nigeria & 3.9 & RBPT & Akinseye et al. [66] \\
\hline Lao PDR & 0.3 & ELISA & Douangngeun et al. [67] \\
\hline India & $30.40^{\mathrm{a}}$ and $41.55^{\mathrm{b}}$ & RBPT and Indirect ELISA & Pathak et al. [68] \\
\hline Uganda & $14^{2, \mathrm{e}}, 29^{2, \mathrm{~d}}$, and $17^{4, \mathrm{e}}$ & IgG and IgM LFA and Milk Ring Test & Miller et al. [69] \\
\hline Cote d'Ivoire & $4.6^{2}$ & RBPT & Kanoute et al. [70] \\
\hline Mexico & $0.52^{4}$ & $\begin{array}{l}\text { Card Testing and Radial } \\
\text { Immunodiffusion }\end{array}$ & Roman-Ramirez et al. [71] \\
\hline Pakistan & $6.3^{\mathrm{a}}, 3.28^{\mathrm{c}}$, and $6.7^{\mathrm{d}}$ & RBPT, RT-PCR, and Milk Ring Test & Ali et al. [72] \\
\hline Costa Rica & $10.5-11.4^{\mathrm{a}}$ and $4.1-6^{\mathrm{b}}$ & RBPT and ELISA & Hernandez-Mora et al. [73] \\
\hline Algeria & 12 & Serology & Kardjadj [74] \\
\hline \multicolumn{4}{|l|}{${ }^{1}$ Buffalo. } \\
\hline \multicolumn{4}{|l|}{${ }^{2}$ Cattle. } \\
\hline \multicolumn{4}{|l|}{${ }^{3}$ Sheep. } \\
\hline \multicolumn{4}{|l|}{${ }^{4}$ Goat. } \\
\hline \multicolumn{4}{|c|}{${ }^{a} \mathrm{RBPT}$, rose Bengal plate test. } \\
\hline \multicolumn{4}{|c|}{ 'ELISA, enzyme-linked immunosorbent assay. } \\
\hline \multicolumn{4}{|c|}{ 'PCR, polymerase chain reaction (RT-PCR, real-time PCR). } \\
\hline \multicolumn{4}{|c|}{${ }^{\mathrm{d}}$ Milk ring test. } \\
\hline \multicolumn{4}{|c|}{ eLFA, lateral flow assay. } \\
\hline \multicolumn{4}{|c|}{ fSTAT, serum tube agglutination test. } \\
\hline \multicolumn{4}{|c|}{ BPAT, buffered plate agglutination test; CFT, complement fixation test. } \\
\hline
\end{tabular}

Table 2. Prevalence studies of brucellosis in ruminants.

demonstrated that ingestion of virulent $B$. abortus causes infection in female water buffalo [81, 82]. Co-mingling of many animals in a small area facilitates disease transmission, and congregation of water buffalo in wallows may be an important factor for spread of brucellosis [83]. 
Brucella spp. taint host units that are skilled of giving those supplement erythritol, henceforth their predilection with carry on with inside units of the genital tracts about animals. Reticuloendothelial cells need a favoring area clinched alongside animals and the primary site in humans, especially human macrophages. [84]. Later confirmation recommends that the host environment must likewise give choline, a fundamental forerunner to the synthesis, toward brucella organisms, of the cell envelope without which those creatures are not virulent $[56,85,86]$.

Brucellosis may be diagnosed through direct and indirect methods. The direct methods include isolating and identifying the bacteria in the samples obtained from the suspect animal, such as tissues from aborted fetuses, placenta, vaginal exudates and milk [39, 186]. Isolating the agent is the safest diagnostic method and is considered the gold standard for diagnosis. However, it presents difficulties concerning sample collection and conservation, as well as those concerning the implementation procedures of the technique. Low bacterial loads in collected specimen can lead to false negative result [57]. Polymerase chain reaction (PCR) assays have been created to diagnose Brucella at the species level (e.g. the Abortus, Melitensis, Ovis, Suis AMOS PCR). These assays are most useful when applied to DNA extracted from a positive culture [57].

On the other hand, the indirect or serological methods consist in detecting antibodies in serum, milk and seminal plasma [87]. These include milk ring test (MRT), serological tests such as the standard agglutination test (SAT) and buffered agglutination test, which are confirmed by the complement fixation test (CFT) and enzyme-linked immunosorbent assay (ELISA) [57]. According to Molnár et al. [88], the serological methods are one of the main bases used to support brucellosis control programs. The correct diagnosis of brucellosis gives support and assurance to the implementation of eradication programs [2].

The most effective measures for controlling and eradicating bovine brucellosis in high prevalence countries or regions are grounded on vaccination of all susceptible host, serologic tests and slaughter/eradication of positive animals [89]. Vaccination is a critical tool pecker to control or eradicate bovine and buffalo brucellosis, because it prevents abortion miscarriage and consequent pasture ley contamination, recognized as major form to transmission of B. abortus to these species. Though RB51 strain has been approved for use in some countries, B. abortus strain 19 (S19) is still the most common vaccine suggested against bovine and buffalo brucellosis worldwide. [3].

Natural resistance to bovine brucellosis was also explored in water buffaloes. These include the candidate gene solute carrier family 11A1 (SLC11A1) through monocyte chemotactic/chemoattractant protein 1 (MCP1), Nramp1 (natural resistance-associated macrophage protein 1) gene, particularly the Nramp1BB genotype [90] and the haplotype pair HYA/HYA at the mannose-binding lectin (MBL) [91].

The broad management system, challenges for the achievement of sterile control projects that were done nationally for huge herds and broad regional dimension, and the confusion that water buffaloes are highly resistant to disease are factors that thwart those control from claiming brucellosis clinched alongside water buffaloes [92, 93]. 


\subsubsection{Bovine tuberculosis}

Bovine tuberculosis (BTb), caused by Mycobacterium bovis, is a chronic and zoonotic bacterial disease. M. bovis is closely related to M. tuberculosis of human, both of which belong to Mycobacterium tuberculosis complex. It remains as an endemic infection in several countries, despite several efforts to control the disease [165, 167, 182, 277]. BTb infects variety of domestic and wildlife hosts, of which is either reservoir or spill-over, wherein buffalo is an example [94, 95].

M. bovis is primarily transmitted between animals by inhalation, though can be transmitted through ingestion and skin inoculation, however, these transmission is less commonly observed [94-97]. Pathogenesis of M. bovis starts after inhalation of bacilli as it adheres to the alveolar surface of the lung and is phagocytosed by macrophages. Then, macrophages phagocytosed mycobacterial antigens and extant them to T-lymphocytes, an important component of immune response. Classical lesions in buffalo are tuberculosis mass in the lungs and lymph nodes, but can also be established in distal sites [98]. Disease resistance is arbitrated by either the innate or the adaptive immunity and therefore the genes related to either of these processes may be candidate genes for BTB susceptibility loci [97].

The information was skewed on BTb in ruminants, which are most of the studies focus of cattle for domestic livestock and African buffalo in the wildlife. Very few peer-reviewed journals on BTb exist for water buffalo. BTb remains a serious problem for animal and human health in many developing countries [108]. Its extensive distribution has drastic negative economic impact (animal mortality and lower milk production output), affecting public health, international trade and tourism [94].

African buffalos infected with BTb show clinical signs only in late stages of the disease course. The clinical signs of BTb in buffalo at such stage include coughing, debilitation, emaciation and lagging when chased $[98,99]$. The incubation period for BTb is 9 months to a year, and infections can be subclinical or dormant for a long period of time and reactivate during periods of stress or in old age [100]. The losses to the cattle industry due to BTb manifests as $10-20 \%$ reduced milk and meat production, infertility and carcass contamination [101]. The epidemic of HIV in developing countries in which M. bovis is present in animals could make zoonotic tuberculosis a serious public health threat to persons [102-104] (Table 3).

Disease prevalence of BTb is 25.3 and $21.6 \%$ for cattle and buffaloes, respectively [115] (Table 3). Although, prevalence of BTb varies greatly among countries [103]. The results of PCR on suspected samples together confirmed $92.5 \%$ cases as Mycobacterium, $86.8 \%$ for M. tuberculosis complex and $77.4 \%$ for M. bovis [116]. In Southern Italy, of all domesticated ruminants, water buffalo (Bubalus bubalis) plays an important economic role. Raw buffalo milk is very important to an Italian product called "mozzarella di buffala" [117]. It is mandatory that herd from which milk is collected should be free from brucellosis and tuberculosis. Tuberculosis has not yet been eradicated in Southern Italy. It has been reported in 2012 that cattle and buffalo has $0.7 \%$ prevalence, and an incidence increase of $0.65 \%$ [115]. The animal level prevalence of BTb has been reported to be 13.5 and14.3\% in Ethiopia and India, respectively $[118,119]$. In Pakistan, previous study conducted in and around Faisalabad city using tuberculin skin test reported prevalence of $5.1 \%$ in cattle and $1.7 \%$ in 
buffaloes [120]. In Lahore, $6.9 \%$ buffaloes showed positive reaction to tuberculin [121]. In Punjab province, 2.45 and $8.48 \%$ buffaloes at two farms were found positive to tuberculin test [122]. Another study reported 3\% tuberculosis prevalence in buffaloes at Faisalabad and Okara [103].

The "gold standard" diagnosis for TB is still the culture identification [123] or DNA amplification by PCR. Although, some indirect tests are used for screening test, the most frequently employed diagnostic test is intradermal tests (ITT), which is based on the inoculation of an M. bovis-purified protein derivative (bovPPD) or concurrent with an M. avium PPD (avPPD). However, sensitivity and specificity is the drawback of this test [124]. The gamma-interferon assay, an in vitro test measuring the production of interferon-gamma (IFN) on blood samples, was previously sensitized with a bovine PPD. Although this test has high sensitivity and specificity, it is costly and has limitations of IFN assay in some countries [32, 125].

\begin{tabular}{|c|c|c|c|}
\hline Locality & Prevalence (\%) & Technique & Authors \\
\hline Uganda & $21.6^{1}$ & Interferon- $\gamma$ & Kalema-Zikusoka et al. [105] \\
\hline Lao PDR & 1 & ELISA & Vongxay et al. [106] \\
\hline Brazil & $5.63^{1}$ & Tuberculin Test & Barbosa et al. [107] \\
\hline El Salvador & $18^{3}$ and $13^{4}$ & SITT & $\begin{array}{l}\text { Linderot de Cardona et al. } \\
\text { [108] }\end{array}$ \\
\hline Ghana & $19^{2}$ & Anigen Rapid BTB test & Amemor et al. [109] \\
\hline Eritrea & 11.3 & SITT & Ghebremariam et al. [110] \\
\hline Spain $^{3}$ & $\begin{array}{l}50.44^{\mathrm{a}}, 83.23^{\mathrm{b}}, 24.92^{\mathrm{c}} \\
4.86^{\mathrm{d}}, 59.42^{\mathrm{e}}\end{array}$ & $\begin{array}{l}\text { Culture, Histopathology, SITT, } \\
\text { Interferon- } \gamma \text {, ELISA, }\end{array}$ & Muñoz-Mendoza et al. [111] \\
\hline Cameroon & $41^{\mathrm{f}}$ and $52^{\mathrm{a}}$ & Post mortem Exam and Culture & Egbe et al. [112] \\
\hline South Africa & $48.4^{\mathrm{g}}$ and $43.1^{\mathrm{h}}$ & $\begin{array}{l}\text { Ziehl-Neelsen Staining and } \\
\text { Multiplex PCR }\end{array}$ & Bhembe et al. [113] \\
\hline $\begin{array}{l}\text { Democratic Republic } \\
\text { of Congo }\end{array}$ & $1.68^{4}$ & Ziehl-Neelsen Staining & Luboya et al. [114] \\
\hline \multicolumn{4}{|l|}{${ }^{1}$ Buffalo. } \\
\hline \multicolumn{4}{|l|}{${ }^{2}$ Cattle. } \\
\hline \multicolumn{4}{|l|}{${ }^{3}$ Sheep. } \\
\hline \multicolumn{4}{|l|}{${ }^{4}$ Goat. } \\
\hline \multicolumn{4}{|l|}{${ }^{\mathrm{a} C u l t u r e .}$} \\
\hline \multicolumn{4}{|l|}{ bHistopathology. } \\
\hline \multicolumn{4}{|c|}{ 'SITT, single intradermal tuberculin test. } \\
\hline \multicolumn{4}{|c|}{ dInterferon- $\gamma$} \\
\hline \multicolumn{4}{|c|}{ 'ELISA, enzyme-linked imunosorbent assay. } \\
\hline \multicolumn{4}{|c|}{ Post-mortem examination. } \\
\hline \multicolumn{4}{|c|}{ gZiehl-Neelsen staining. } \\
\hline hPCR, polymerase cha & reaction. & & \\
\hline
\end{tabular}

Table 3. Prevalence studies of bovine tuberculosis in ruminants. 
Serological assays (ELISA) have been suggested as an ancillary diagnostic test in screening or to identify immuno-compromised animals in a herd [32,125]. For this purpose, some antigens have been assessed with variable results [34].

MPB70, a protein secreted by M. tuberculosis complex species, is identified as an early B cell target in M. bovis infection, and can be robustly identified in infected cattle. A study verified that ELISAs using MPB70 as capture antigen was found to have acceptable specificity and sensitivity [55].

Improving the diagnostic capability is another area for improvement to screen and detect all infected animals especially the subclinical cases. Recently, serologic assays (gamma-interferon assay, the MAPIA and rapid tests) are efforts to provide single point of contact tests, a valuable tool in disease surveillance of free-ranging wildlife [126].

Historically, spread of M. bovis is controlled in a domestic cattle herd via whole-herd skin testing, slaughter testing and movement monitoring herds. In addition, the milk pasteurization is important in controlling the zoonosis of tuberculosis. In past years, disease transmission between humans, domestic animals and wildlife has increased. Once a disease becomes endemic in a wildlife population, disease control becomes much more challenging [126].

$\mathrm{BTb}$ is traditionally controlled using quarantine of infected or suspected herds, slaughter testing and milk pasteurization $[94,127]$. Although traditional control programs have eradicated or almost eradicated the disease from farm animals and pets in some developed countries [128, 129], BTb is still prevalent in Great Britain, Ireland, New Zealand, Africa and many more developing countries $[98,130]$. In fact, tuberculosis has a great negative impact on economy and public health $[95,130]$.

Poor husbandry and biosecurity, like co-mingling of infected livestock with wild animals, increases the spread of disease and the number of reservoir host. With this, the disease cannot be eradicated since the bacteria are circulating within the herd and reservoir hosts [126]. Controlling population densities of wildlife reservoirs and successfully implementing proper biosecurity to minimize interaction between wild and domestic animals can help to control and prevent the horizontal transmission of the disease. However, these methods may be insufficient in eradicate the disease. In addition, focal depopulation of wildlife reservoir is another control measure that can be employed successfully. Unfortunately, due to biodiversity and animal welfare issues, this extreme eradication measure should not be patronized [126]. Regardless of the methods employed, the control of bovine tuberculosis once establishes itself in a wildlife maintenance host population is generally a long-term commitment. It appears that BTb in its many forms remains an important disease in both domestic and wild animals and that its eventual control will remain an on-going concern for many decades into the foreseeable future [126]. Prevalence of tuberculosis is high in developing countries because the control strategies are lacking or poorly executed [128, 129].

Development of vaccines for wildlife is the articulated theme by researchers worldwide for control to eradication of tuberculosis. The vaccine should reduce the shedding of $M$. bovis or prevent the development of the disease in reservoir hosts. Development of an oral-bait vaccine is objective of researchers to immunized wide range of free-range wildlife species. 
In addition, researchers are also thinking of developing a vaccine that can differentiate its immunization against wild-type M. bovis infection following animal death. This may mean that researchers are thinking of a genetically engineered vaccine is more than the conventional BCG-based vaccine [126].

\subsection{Viral}

\subsubsection{Bovine ephemeral fever}

Bovine ephemeral fever (BEF) is an economically important disease affecting cattle, yak and water buffalo among other ruminants. This disease is caused by the arthropod-borne bovine ephemeral fever virus (BEFV) belonging to the family Rhabdoviridae under the genus Ephemerovirus [131]. Although it is not contagious among vertebrates, its epizootiology is consistent with insect-borne transmission. Infected animals are characterized by high fever, spontaneous abortion, lameness or paralysis [132-134] and its distribution among bovines covers Africa, Middle East, Australia and Asia [135].

Although its origin is quite unclear, the first report of BEF was documented in China in 1955, while the first strain of BEFV, the JB76H strain, was isolated from an infected dairy cattle during an epidemic in the country in 1976 [136, 137]. Subsequently, the disease was also reported in some countries in the East Africa, Rhodesia, Kenya, South Africa, Indonesia, India, Egypt, Palestine, Australia and Japan [138, 139]. Though bovine ephemeral fever has been endemic in several areas in Africa, Australia and Southern Asia, the advancement of cattle industry has enhanced its dispersal into a larger area [134, 140]. On the other hand, the disease has never been reported in the Western Hemisphere, North and South America. Serological evidences also showed that New Zealand and Pacific Islands are not affected by the disease. Presently, bovine ephemeral fever is enzootic in South Africa, India, Japan and some areas in Australia [141].

Many factors propose that mosquitoes are the main vectors of the disease. Commonly observed clinical signs are abrupt fever of about $41^{\circ} \mathrm{C}$ high, lasting for 1-3 days with severe decrease in milk production, lethargy, ocular and nasal discharge, stiffness, dyspnea, depression, salivation, anorexia, lameness and ruminal stasis, [142] though in some reports, prolonged paralysis and ataxia were observed in some animals following the acute stage of infection. Severe cases can lead to mortality which might be caused by exposure, starvation or even pneumonia [39].

BEF is usually diagnosed through serological assays. If the animal was exposed previously to another ephemerovirus, anamnestic responses to BEFV during the first infection can happen. The most frequently used diagnostic assays are the ELISA and viral neutralization [143]. In some countries, molecular methods such as reverse transcription polymerase reaction and real-time loop-mediated isothermal amplification are also being done for faster and more sensitive detection of the disease [141].

Under the electron microscope, the BEF virus has a bullet shape with fringe of fine surface projections measuring about $80 \times 120 \pm 140 \mathrm{~nm}$. However, South African strains are mostly conical in shape resembling the bullet-shaped Asian and Australian strains serologically. The 
citrated blood from affected cattle remains infectious at $48^{\circ} \mathrm{C}$. However, there is a decrease of infectivity of the virus at extreme $\mathrm{pH}$ conditions (2.5 or 12) within $10 \mathrm{~min}$. Consequently, the virus is inactivated within $10 \mathrm{~min}$ at $568^{\circ} \mathrm{C}$ and $18 \mathrm{~h}$ at $378^{\circ} \mathrm{C}$ [144].

Isolation of the virus is done by inoculating leucocyte from an infected cow into suckling mice ( $1 \pm 3$ days old) intracerebrally or suckling hamster and rats. The virus grows very well in BHK-21 cells inoculated from mouse brain or bovine leucocyte suspension. It also grows in bovine kidney, hamster lung, Vero and Aedes albopictus cell lines and hamster lung tissue culture [145].

Handling of the disease includes the usage of non-steroidal anti-inflammatory drugs and administration of calcium borogluconate to hypocalcemic animals in order to reduce the clinical signs. Vaccination is also considered as the most effective approach to control the disease. Previous studies have applied live attenuated, inactivated, subunit and recombinant vaccines experimentally and commercially. However, live vaccines generally induce more prolonged immunity [146].

\subsubsection{Rotavirus infection}

Rotavirus belongs to the family Reoviridae under the genus Rotavirus. The virion has a triple layer capsid that covers a genome of double-stranded RNA. Its envelope is lipid-free and has three concentric layers of protein made up of 3 of the 13 proteins that the rotavirus genome encodes [147]. The most common rotaviruses isolated from human and animals have a common group antigen present on the major inner capsid protein VP6 and are now categorized into group A [148] which are commonly isolated from rotaviral diarrhea cases. Other rotaviruses that lack the said antigen are characterized as non-group A rotaviruses and are classified into groups B, C, D, E, F and G. Furthermore, group A rotaviruses are subdivided into subgroups I and II, based on their antigenicity of a separate domain present in the VP6 [148, 149]. The two outer capsid proteins, VP7 and VP4, independently produce neutralizing antibodies, induce protective immunity, and are used to classify rotaviruses into G (for glycoprotein) and P (for protease-sensitive) types, respectively [150]. Neonatal diarrhea caused by RVA boRV projects significant economic loss in the dairy and beef industry due to increased morbidity and mortality, treatment costs and reduced growth rates [150].

The virus attacks the villi upon its entrance in the small intestine suppressing effectively absorption of nutrients into the animal's body that leads to dehydration. The incubation period of the virus lasts for about 12-24 hours and the infected calves are usually feverless [147]. Clinical signs include runny diarrhea, dehydration and loss of appetite and if severity increases, it leads to mortality [151]. No specific treatment is being used for this disease. Hence, replacing lost fluids and restoring the balance of the body's important electrolytes are most applicable. Usage of antibiotics is not recommended, however, it can be administered if there is a presence of secondary infection caused by bacteria [152]. Animals that have recovered often return to their normal bodyweight in around 10-28 days after the infection [147].

Transmission of the disease to other animals usually occurs upon contact with infected feces [153]. Infected calves excrete the virus in their feces up to the age of 6-8 weeks [154]. It is quite 
hard to eradicate for it survives for several months and can resists several disinfectants [152]. Also, the disease is considered as zoonotic [155]. Thus, vaccines are used for the prevention of the disease [156]. Also, passive immunity plays a vital role in the prevention of rotavirus infection. The transfer of colostral antibodies provides early immunity in new born animals and serves as the most important form of protection for a newly born calf. However, this type of protection lasts for only 3-4 days, thus it only reduces the rotaviral diarrhea rather than eliminating it. In this regard, continuous colostrum feeding is advised [157].

Diagnosis for the disease is also being carried out using antigen-antibody assays along with PCR and electron microscopy [188]. Also, the disease can be detected through agglutination and polyacrylamide gel electrophoresis. Detection techniques dealing on the viral RNA such as RT-PCR, nested RT-PCR and real-time qPCR are even becoming a more widely used way of diagnosis [147].

\subsubsection{Bovine viral diarrhea}

Bovine viral diarrhea virus (BVDV) is another significant pathogen causing respiratory and reproductive illnesses infecting ruminants that leads to various clinical problems including abortion. BVDV belongs to family Flaviviridae under the genus Pestivirus, subdivided into four well-known species: bovine viral diarrhea virus 1 (BVDV-1), bovine viral diarrhea virus 2 (BVDV-2), border disease virus (BDV) and classical swine fever virus (CSFV), previously known as hog cholera virus. BVDV has a worldwide distribution and its natural hosts include a wide range of domestic and wildlife animal populations, ruminants in particular $[158,159]$. Previously, another type of BVDV was identified: the HoBi-like pestiviruses, also known as the bovine viral diarrhea virus 3 [160]. This type of BVDV has been occasionally reported from naturally infected cattle in Brazil, Asia and Europe [161].

Clinical symptoms of the disease include diarrhea, mucosal disease and reproduction dysfunctions such as abortion, teratogenesis, embryo resorption, fetal mummification and stillbirth [45]. Also, birth of an immunotolerant calf with persistent infection (PI) is also possible if the mother has been infected by the disease from 50 to 125 days of gestation [162]. The most birth defect among calves caused by this disease is cerebral hypoplasia characterized by ataxia, tremors, wide stance, stumbling and failure to nurse. Severe cases can lead to death [160].

The disease is more frequently transmitted vertically leading to births of persistently infected calves. On the other hand, it can also be transmitted horizontally through direct contact among infected animals [163, 164]. There is no known treatment for this disease and only supportive therapy is being applied. However, upon detection, the infected animal should be culled [151].

Detection methods for the disease include virus isolation, immunohistochemistry, polymerase chain reaction and serology depending on the setting of the disease. Immunohistochemistry is more applicable for herd surveillance and screening since samples may be collected from cattle of any age. Thus, allowing simpler sampling, stable samples for transport and results are not affected by passive antibodies. On the other hand, polymerase chain reaction is 
advantageous for pooled blood or milk samples since trace amount of virus can be identified using this technique [45]. Both virus isolation and polymerase chain reaction methods require subsequent testing within 3 weeks of the first testing to discriminate transient infection from persistent infection [165].

The presently known control measure for BVDV is through vaccination [166]. Two types of vaccine for BVDV are being used: the modified live virus (MLV) vaccines and the killed virus $(\mathrm{KV})$ vaccines. MLV vaccines have few antigens and only require one dose during the initial immunization step since the viral antigen replicates in the vaccinated animal thus, boosting the immunogenic mass. However, this vaccine is not stable in varying temperature and can be easily deactivated by some chemicals. Also, it is not recommended to administer this vaccine to pregnant cattle. On the other hand, the KV vaccines are more expensive since it requires more antigens per dose and more than one dose of vaccine is usually given during initial immunization, but this type of vaccine remains stable in varying temperature and are not easily deactivated by chemicals [167].

\subsection{Protozoal}

\subsubsection{Trypanosomiasis (Trypanosoma evansi)}

Trypanosoma evansi, the causative agent of Surra, is a blood and occasional tissue parasite to variety of animals transmitted by biting flies [168] (Figure 1). T. evansi-infected animal exhibits fever, anemia, weakness and nervous signs that are responsible for low production yield of meat, milk, draught power, fertility and even manure. In the absence of proper treatment, chronic wasting is observed leading to abortion and death [169].

Among salivarian trypanosomes, T. evansi has the widest host range, however, susceptibility is dependent on host immune system and can vary geographically [170]. In theory, the wide range of hosts of $T$. evansi is attributed to the deletion of maxicircle kinetoplast DNA [171-173]. This is also the reason why T. evansi can no longer be transmitted by Glossina flies [174]. Thus, the transmission of the parasite is through biting flies. Through the new vector, $T$. evansi spread from tsetse belt of Africa toward the rest of the world through livestock exportation. However, it is still absent in Australia [170, 175].
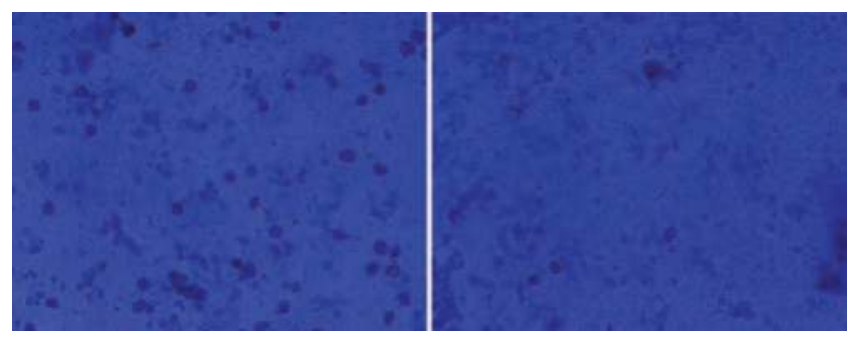

Figure 1. Presence of adult T. evansi upon blood parasite examination (BPE) of an infected water buffalo (Photo from Philippine Carabao Center). 
Originally, the principal host of T. evansi is the camel, however, it is also present in equids and other mammals, like the water buffalo. In Asia, T. evansi is one of the major blood parasites of water buffaloes; and considered as economically important disease in the Philippines [169]. In the Americas, it is found in water buffaloes with prevalence of $40 \%$ in some cases. However, clinical signs of trypanosomiasis are reportedly due to T. vivax than T. evansi [176].

Trypanosomiasis caused by T. evansi has been categorized as mild, chronic or subclinical disease of Bovinae, mainly in Latin America and Africa [177] (Table 4). One-third of a century in Asia, numerous reports displayed Surra still as major disease of cattle and water buffaloes, especially in Southeast Asian countries. Infection results in anemia, great loss in the production of meat, milk, draught, leading to total wasting and death of the animal [175]. In Indonesia, clinical signs disrupt the heifer's estrus cycle [178]. In Thailand, novel clinical signs are observed with the addition of edema of the legs, conjunctivitis and dyspnea [179]. Meningoencephalitis is the most observed nervous signs [180]. Imported buffaloes from Australia are very susceptible to the infection due to absence of the parasite in the source

\begin{tabular}{llll}
\hline Locality & Prevalence (\%) & Technique & Authors \\
\hline Jordan & $8.2^{1}$ & BPE and MIT & Abo-Shehada et al. [183] \\
& $9.6^{2}$ & & \\
Tanzania & $30.4^{\mathrm{a}}$ & PRF-LAMP & Laohasinnarong et al. [184] \\
& $0.6^{\mathrm{b}}$ & PCR & \\
Spain (Canary Islands) & 5 & ELISA & Rodriguez Diego et al., [185] \\
North Vietnam & 22.4 & CAT & Nguyen et al., [186] \\
South Africa & $23.7^{\mathrm{c}}$ & ELISA & Nguyen et al., [187] \\
& $29^{\mathrm{d}}$ & TeGMG-4r ELISA & \\
& $19.9^{\mathrm{e}}$ & ICT & Kocher et al., [188] \\
Thailand & $12.2^{\mathrm{b}}$ & Indirect ELISA & Laohasinnarong et al. [189] \\
Zambia & 6.1 & Microscopy & \\
& $7.5^{\mathrm{b}}$ & PCR & Musinguzi et al. [190] \\
\hline
\end{tabular}

${ }^{1}$ Camel.

${ }^{2}$ Horses.

${ }^{3}$ T. vivax.

aPRF-LAMP, loop-mediated isothermal amplification.

${ }^{b} \mathrm{PCR}$, polymerase chain reaction.

'ELISA, enzyme-linked immunosorbent assay.

${ }^{\mathrm{d}}$ TeGMG-4r ELISA.

eICT, immunochromatographt test.

BPE, blood parasite examination; CAT, card agglutination test.

Table 4. Prevalence studies of ruminant trypanosomiasis worldwide. 
country. A study in Vietnam in 1971-1981 concluded that 10\% of buffalo deaths in Vietnam following massive importation of buffalo from Thailand and Cambodia; serological studies confirmed $10-40 \%$ are positive. Similarly, $15-54 \%$ of cattle and buffaloes are seropositive in Thailand [181]. In the Philippines, two patterns demonstrated are acute disease and chronic wasting disease. Similar Vietnam study, $10 \%$ of buffalo deaths within months in the Philippines are attributed to trypanosomiasis [70]. In addition, an alarming rate of $47 \%$ of abortion is attributed to trypanosomiasis [170, 182] (Table 4).

Anemia is one of the most consistent clinical sign of trypanosomiasis. In water buffaloes, trypanosomiasis infection causes a significant drop in hemoglobin concentration, packed cell volume and red blood cell count, creatinine and urea and liver alkaline phosphatase, in contradiction, total leucocyte count increases together with lactate dehydrogenase enzymes (LDH) activity, globulin, total bilirubin and indirect bilirubin, highlighting a link between immune and metabolic disorders [169, 191, 192].

The most common therapeutic drug used against surra is diminazene aceturate, though isometamidium chloride, cymelarsan, suramin and quinapyramine can also be used [193]. A dose of $7 \mathrm{mg} / \mathrm{kg}$ bw intramuscularly of diminazene aceturate (DA) is used to treat animals infected with T. evansi. In cases of high parasitemia, $3.5 \mathrm{mg} / \mathrm{kg} \mathrm{bw}$ dose of DA is used to reduce the parasitemia and a second injection of the $7 \mathrm{mg} / \mathrm{kg}$ bw is used to ensure that all parasites are killed. If the treatment failed, isometamidium chloride and cymelarsan can be used separately at $0.5 \mathrm{mg} / \mathrm{kg}$ bw by deep intramuscular injection in cattle and water buffaloes [170, 194].

In the past, T. evansi could only be eradicated from areas where it can be detected and controlled at a very early stage. During quarantine, infected animals should be euthanized and later dispose the carcass carefully. On the other hand, if the infection is enzootic, eradication is impossible due to existence of wide variety of domestic and wild host, transmission by nonspecific vectors and due to subclinical carriers. Under these conditions, reduction of infected areas is highly improbable, however, its spread can be easily predicted. Thus, T. evansi has an unobvious spreading pattern [169].

\subsubsection{Neosporosis}

Neospora caninum is an intracellular, obligate protozoan parasite of phylum Ampicomplexa. It causes abortion in cattle and water buffaloes worldwide impacting dairy and beef industries [195]. Aside from cattle, literatures cite that water buffaloes of Asia are also infected by the parasite [216]. In the same environment and potential exposure, water buffalo shows a higher seroprevalence than cattle (48.3 versus $28.3 \%)[195,196]$.

In a recent worldwide review, seroprevalence of dairy and beef cattle is at 16.1 and $11.5 \%$, respectively, and in water buffalo is at least higher than cattle [195]. Vertical transmission is the most persistent way the parasite stays in the herd [89]. Viable N. caninum can be isolated from tissues of naturally infected water buffaloes and this indicates that it is an intermediate host for the parasite [197]. In Brazil, four out of seven dogs that have ingested infected buffalo brain have shed oocysts and gamma-interferon knockout mice have develop clinical neosporosis after oral inoculation of oocysts [198]. 
The initial claim on seroprevalence of $N$. caninum in buffalo is reported in 1995 from blood collected at a slaughterhouse in Vietnam [199]. Since then, various counties have reported prevalence of N. caninum. Despite the clear association of N. caninum and abortion in cattle [32, 33], it is less commonly seen in water buffalo [195, 200]. In addition, experimental infection that would normally cause abortion in cattle is not observed in water buffalo. However, studies of Chryssafidis et al. [201] and Konrad et al. [200] demonstrated that experimental infection of pregnant water buffalo in early gestation with $N$. caninum will result in abortion and lesions in placentomes and fetuses. In addition, experimental infections results in seroconversion (measured via IFAT) at 7-11 days post-infection, peaking at 3 months and persisting up to a year $[185,197]$. However, a $20 \%$ increase in seroprevalence is reported in aborting than non-aborting cases in water buffaloes. Despite several researchers reporting the high seroprevalence in buffalo herd, a gap still exists in N. caninum abortion cases (Table 5) [202]. N. caninum stimulates an immune response from $\mathrm{T}$ helper (Th) 1 immune response that limits its multiplication [120], however, this same scenario leads to placental damage and, ultimately in abortion [203, 204].

\begin{tabular}{|c|c|c|c|}
\hline Locality & Positive (\%) & Technique & Authors \\
\hline Egypt & 68.0 & DAT & Dubey et al. [32] \\
\hline Vietnam & 1.5 & IFAT and ELISA & Huong et al. [205] \\
\hline Brazil & 36.5 & IFAT & Gondim et al. [206] \\
\hline Italy & 34.6 & IFAT & Guarino et al. [207] \\
\hline Brazil & 56 & IFAT & Souza et al. [208] \\
\hline Brazil & 63.9 & IFAT & Fujii et al. [209] \\
\hline Brazil & 70.9 & IFAT & Gennari et al. [210] \\
\hline Brazil & 14.6 & ELISA & Vogel et al. [211] \\
\hline China & 0 & ELISA & Yu et al. [212] \\
\hline Argentina & 64.0 & IFAT & Campero et al. [213] \\
\hline Iran & 37.0 & ELISA & Hajikolaei et al. [214] \\
\hline Philippines & 3.8 & ELISA & Konnai et al. [215] \\
\hline Philippines & 27.3 & ELISA & Abes and Divina [216] \\
\hline Brazil & 40.9 & IFAT & Silva et al. [217] \\
\hline Pakistan & 54.7 & ELISA & Nasir et al. [218] \\
\hline Argentina & 42.2 & IFAT & Konrad et al. [200] \\
\hline Italy & 51.0 & ELISA & Auriemma et al. [219] \\
\hline Brazil & $55.6^{\mathrm{a}}$ and $48.9^{\mathrm{b}}$ & IFAT and ELISA & Silva et al. [79] \\
\hline Argentina & 43.3 & IFAT & Moore et al. [196] \\
\hline Morocco & 8.52 & ELISA & Lucchese et al. [20] \\
\hline Lao PDR & $68.9^{\mathrm{a}}$ and $7.8^{\mathrm{b}}$ & ELISA & Olmo et al. [25] \\
\hline
\end{tabular}

Table 5. N. caninum serological studies conducted on water buffalo worldwide. 
In a Pakistani study, seroprevalence of N. caninum is high $(54.7 \%)$ and corroborated that aborted cases have a higher seroprevalence than non-aborted cases (78.9 versus 55\%) [125]. In Italy, N. canimum DNA has been detected in aborted fetuses [219]. Underreporting might be the reason for a lower seroprevalence in water buffaloes than cattle, because water buffaloes are typically used in less economically stable areas [197]. In general, water buffalo reproductive system is less efficient than cattle and reproductive losses are sometimes unnoticeable. In addition, reproductive physiology of water buffaloes is different from cattle because they are seasonal breeders [49, 197].

Serology, molecular assays and histological analysis are some diagnostic examinations done for neosporosis [32]. Lesions caused by N. caninum in water buffaloes are uncommon, due to few studies showing direct association between the parasite and abortions [197, 218, 219]. The lesions seen naturally aborted buffalo caused by N. caninum consists of non-suppurative inflammation in placenta, brain, heart and other organs [33]. In a study in Italy, a herd with $34.6 \% \mathrm{~N}$. caninum seropositive, four aborted fetuses' organs were examined histopathologically. Nonsuppurative encephalitis and myocarditis were observed in two fetuses and the other two were observed to have protozoan-like cysts, however, identity was not confirmed [207]. In another study in Italy, lesions of aborted fetuses were confined to the brain and heart [219]. Polymerase chain reaction (PCR) testing detected N. caninum DNA in all fetuses. The samples were also tested for other abortifacients and samples were only positive for N. caninum DNA [219].

Several serological assays (NAT and IFAT) have been used to measure seroprevalence and describe the epidemiology of N. caninum in water buffalo [197]. Overall, researchers have used developed and validated assays for cattle to water buffaloes. However, majority of research studies conducted on water buffaloes used a high cut-off value of 1:100 or above that mostly missed animal with lower titers. Limited support has been carried out, except from recent studies. First, subunit ELISA is compared to standard indirect cattle-specific IDEXX ELISA resulting in high values in kappa statistics, signifying respectable agreement. Another study compared the pan-ruminant indirect ELISA by IDEXX to IFAT, cutting-off threshold substantially downward and arriving at a high diagnostic test performance [220].

Calves positive for the disease can be treated with toltrazuril to prevent vertical transmission in small scale farming, however, this method is not recommended in large scale farming [221]. There is an available vaccine against $N$. caninum (Neoguard ${ }^{\circledR}$ - irradiated tachyzoites), however, efficacy is at mostly $50 \%$. In addition, there is an available attenuated live vaccine (NC-Nowra ${ }^{\circledR}$ ) that demonstrate higher efficacy, but at a higher cost and limited stocks and shelf life [55, 221].

As stated earlier, the parasite is transmitted vertically in the herd. Consequently, it is best to prevent and control transmission of the parasite. In addition, Dubey et al. [31] reported that another way of controlling neosporosis is through proper biosecurity measures: (1) quarantine of new animals, (2) preventing the entry of wild carnivores and rodent control in the farm, (3) feed, water and semen safety test and (4) reduce stress to the suspected animals [221].

\subsubsection{Cryptosporidiosis}

Cryptosporidium spp., a parasite under phylum Apicomplexa, has a wide range of hosts including humans and domesticated and wild animals [222]. It causes diarrhea in humans and 
animals, however is self-limiting to immunocompetent hosts. In addition, young and immunocompetent host may die of life-threatening diarrhea [223, 224]. Livestock are susceptible to Cryptosporidium spp., causing significant production losses of diminished weight gain, stunted growth, neonatal deaths, decreased milk production $[84,137]$ and additional cost in veterinary drugs [137].

Cryptosporidiosis in cattle is commonly caused by four major Cryptosporidium spp. namely: C. parvum, C. bovis, C. ryanae and C. andersoni [225]. The major contributor to cryptosporidiosis zoonosis transmission is C. parvum, and dairy calves are its most common reservoir host $[35,226]$. Dairy calves play as the source of infection and contaminate to the environment due to high prevalence and great oocysts shedding (millions to billions oocysts per animal) [227]. Cryptosporidium oocysts can persist in the feces and environment from few weeks to months [228].

The members of the genus Cryptosporidium have indistinguishable morphologic characteristics [226]. With this, molecular assays are used to differentiate Cryptosporidium spp. of animals in species and subtype levels. These studies further improve the understanding of public health importance and interspecies transmission of Cryptosporidium spp. The variances of infection rate in animals are attributed to variances in age, breed, season, environmental conditions and husbandry practices [229]. As the animals became older, infection rate decreases up to $0.48 \%$. These results corroborated to reports of Abou-Eisha [230] and Amer et al. [231] for adult water buffaloes of Egypt and Rodriguez Diego et al. [185] in buffalo of Cuba, stating that no oocyst may be found in adult buffalo due to resistance of buffalo as specie as they grow older or immunity due to previous infections. On contrary, it might also be attributed to sensitivity of microscopic tests [229]. Table 6 shows studies related to prevalence of Cryptosporidium in water buffaloes.

Cryptosporidium and Giardia commonly cause protozoal enteritis of human and animals [245-248]. Oocysts or cysts of both genera spread through feco-oral route via direct contact of infected feces to food and water [249-251]. Clinical manifestation may vary from selflimiting $[252,253]$ to life-threatening diarrhea [254-256] depending on the immunity of the affected individual [238]. Humans are infected with a variety of species and genotypes of Cryptosporidium [257] and Giardia [258]. However, previous molecular-based studies suggest that C. hominis, C. paroum and G. duodenalis assemblages A and B are most common cause for human disease cases $[87,238,259,260]$. C. hominis is transmitted only through human to human [261], while, C. parvum and G. duodenalis are transmitted through human to human or animal to human [238, 260, 261].

Studies have shown that livestock is a main source of giardiasis and cryptosporidiosis in humans from claims of different molecular-based studies [199, 238, 262]. Many studies proved that cattle are carriers of various zoonotic species of Giardia and Cryptosporidium [263-265]. Santin et al. [264] reported that C. parvum is predominantly found in sucklings, C. bovis and C. ryanae in weaned cattle and C. andersoni in adults. In contrast, little is known about the variety of species and genotypes found in water buffaloes (Bubalus bubalis) [238]. In developing countries, water buffalo plays a role in agricultural economics from draft power and transportation to meat and milk production, and into some extent hide and leather industries [245]. Large ruminants, cattle and buffalo, excrete bulk fecal waste daily, thus, environmental contamination and potential outbreak of Cryptosporidiosis is imminent [199, 238, 266]. 


\begin{tabular}{llll}
\hline Locality & Prevalence (\%) & Technique & Authors \\
\hline Italy & 14.7 & ELISA & Saralli et al. [232] \\
Spain & - & PCR-RFLP & Gomez-Couso et al. [233] \\
Italy & 34.9 & ELISA & Rinaldi et al. [234] \\
Egypt & 14.19 & Fecal Examination & El-Khodery and Osman [33] \\
Egypt & 22.5 & Sheathers sugar Floatation and Modified ZN & Shoukry et al. [235] \\
Pakistan & 24.0 & ZN & Nasir et al. [236] \\
Philippines & $5-50$ & Kinyoun Acid Fast Test & Villanueva et al. [22] \\
India & 38.3 & Fecal Examination & Bhat et al. [237] \\
Nepal & - & PCR-RFLP & Feng et al. [227] \\
Australia & 12.2 & PCR & Abeywardena et al. [238] \\
South Africa & 2.8 & PCR-RFLP & Abu Sarma et al. [239] \\
Egypt & 32.2 & PCR & Helmy et al. [240] \\
Italy & 14.2 & ELISA & Galiero et al. [241] \\
Egypt & 1.29 & ZN & Mahfouz et al. [229] \\
China & 43.0 & PCR & Ma et al. [242] \\
Brazil & 48.2 & nPCR & Aquino et al. [243] \\
Australia & $30^{1}$ and $12^{2}$ & qPCR & Zahedi et al. [244] \\
\hline
\end{tabular}

${ }^{1}$ Domesticated/farmed buffalo.

${ }^{2}$ Wild buffalo.

PCR, polymerase chain reaction (qPCR, real-time PCR; nPCR, nested PCR; PCR-RFLP, PCR restriction fragment length polymorphism); ELISA, enzyme-linked immunosorbent assay; ZN, Ziehl-Neelsen acid fast.

Table 6. Prevalence of cryptosporidiosis in different countries.

Cryptosporidium spp. invades the epithelial lining cells of the jejunum and to some extent, in immuno-compromised individuals, the ileum [267]. Parasite invasion destroys the epithelial lining of the small intestine leading to villous atrophy, preventing nutrient absorption and causing diarrhea [225, 238, 245].

Still, cryptosporidiosis is self-limiting, but treatment can help manage the disease especially for the immuno-compromised animals. In ruminants, halofuginone, synthetic drug from quinazolinone, has therapeutic effect against cryptosporidiosis [268]. A study on the efficacy of halofuginone against cryptosporidiosis has promising results due to its capacity to reduce oocysts excretion and diarrhea, and delay the onset of infection in calves infected with $C$. paroum [269].

Though there are plenty of treatment regimen, prevention is still the best option in protecting animals and humans against Cryptosporidium spp. Identifying critical control points in husbandry and health management is the key requirement in preventing and controlling these parasites [238]. 


\subsection{Fungal}

\subsubsection{Deg Nala disease}

Deg Nala is a disease of water buffalo characterized by lameness, edema of the extremities, gangrenous ulceration or necrosis of mouth, ears, hooves and tail (sloughing of epidermis) (Figure 2), general wasting, recumbency and eventual death [270]. The condition is usually afebrile and limits the movements of the affected animals due to painful condition of the legs [271]. It affects the milk yield of dairy animals due to involvement of udder and inguinal canal. This leads to significant loss of milk yield which has not been quantified so far [271].

The disease is named due to its first occurrence around Muridke (District Sheipura), an area bordering the course of Nala Deg (a monsoon rain water stream) in the Indo-Pakistan region, which was first reported in the 1930s [271].

Deg Nala causes serious concern to the farmers and shows a severe impact on rural economy. It is often overlooked and misdiagnosed as foot and mouth disease and/or mange infection [272].

The disease is considered to be caused by mycotoxin produced mainly by Fusarium spp. Different species of fungi such as Aspergillus spp. and Penicillium spp. are also reported cause this disease [273]. Meanwhile, Indian researchers reported the Deg Nala is due to excess ingestion of toxic amount of selenium (Se) in rice straw grown on selenium-rich soil [272-274].

Several Fusarium spp. were isolated, including F. oxysporum, F. equiseti and F. moniliforme in experimental infection. However, only F. oxysporum showed clinical signs of Deg Nala disease 20-23 days post-infection in one study. However, it should be noted that the number of affected animals may be due to either variation in the susceptibility of the water buffaloes or variability of pathogenesis of strains of Fusarium spp. [274].

The mycotoxin produced by the metabolism of Fusarium fungus grown on paddy/rice straw dissolves the collagen and elastin into collagenase and elastinase, respectively [275]. As a result, the dependent parts of the ear, tail and foot blood supply is obstructed due to action of mycotoxins performing cutaneous vasoconstriction, and ultimately tissue die of anoxia [276].

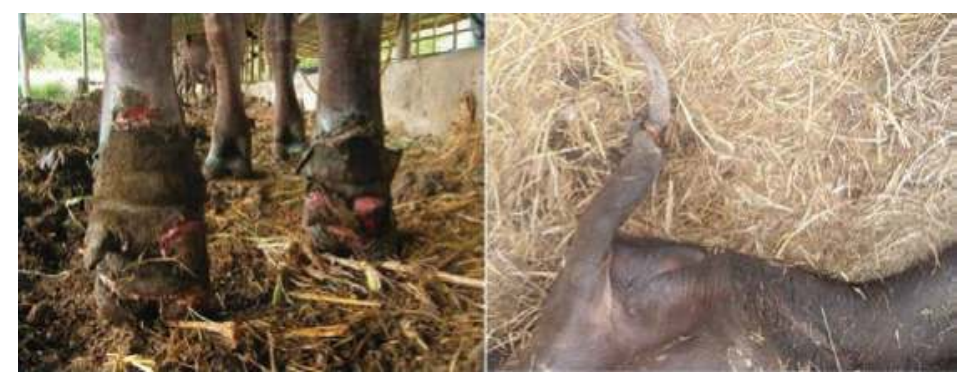

Figure 2. Typical signs of water buffaloes with Deg Nala disease, including gangrenous ulceration or necrosis of the hoof (left) and tail (right) (photo from Philippine Carabao Center). 
The animals fed with Fusarium spp. mycotoxin-infected rice straw experienced loss in body weight due to anorexia and increased tissue catabolism. The progressive posterior weakness may be due to degenerative changes of adjoining musculature. In Deg Nala endemic regions, the disease develop upon release of fungi toxin compounds fostered under promotive environmental settings such as temperature, humidity and water content of rice straw. The unique characteristic of Deg Nala is its confinement to a particular endemic region which may be explained by the need of optimal temperature for fungal growth. Improper storage practices of rice straw as feedstock for water buffaloes is of utmost importance followed by the rural farmers which make it more likely to spoil with fungal contamination [272].

In the case of chronic selenium toxicosis, the disease is more prevalent in peak winter season along with feeding of lush green fodder with high moisture content and mostly those in the rice growing parts of some countries such as India [271-274]. Feeding of green fodders and cereal straws containing 1.1-24 times the upper toxic limits of 5 ppm cause Se toxicity in animals [277]. For indicators of SE condition of an animal, blood SE plus erythrocyte glutathione peroxidase activity are valuable. Blood SE levels can be classified as impending toxicity, toxic and highly fatal for 1.5-1.75 ppm, above $2 \mathrm{ppm}$ and exceeding $3.4 \mathrm{ppm}$, respectively [278].

Buffalo are more frequently affected than cattle and younger animals appeared to be more susceptible. Arora et al. [279] reported chronic selenium toxicity, as a result of Deg Nala disease in buffaloes. Arora et al. [279] reported that $80 \%$ of Deg Nala was cured by feeding pentasulfate mixture [273].

The administration of oxytetracycline is effective at early stage of Deg Nala disease in buffaloes [280]. Also, cases of Deg Nala disease have been successfully treated using proprietary pentasulfate mixture based on sulfur and Se antagonism [279]. Antagonism between arsenic (As) and Se, whereby each reduces the toxicity of the other, has been reported in animal models [281, 282]. Proper management of the wound is recommended for complete recovery of the animal.

It is advisable to stop feeding mold-smelling straw to the animal and to prevent contamination of lesion of animal to dust and dirt. Inadequate postharvest drying of rice plants before stacking and stacking at low-lying places or near water channels were the factors identified with occurrence of the disease [283].

\subsection{Endoparasites}

\subsubsection{Fasciolosis}

Fasciolosis is an endoparasitic disease caused by a trematode known as Fasciola species (F. gigantica and F. hepatica). This disease occurs in almost every tropical and subtropical countries with $F$. gigantica as most common in Africa and Indian subcontinent, Hawaii and the Philippines (Table 7). Fasciolosis epidemic in tropical regions of Southern and South East Asia and Africa is caused by F. gigantica. F. gigantica and F. hepatica share a geographical distribution in most African and Asian counties and occasionally in the same country, however, the environmental requirements of the snail intermediate hosts and the harbored flukes are distinguishable [284]. 
One of the leading causes of morbidity and mortality in ruminants worldwide is Fasciolosis. Small ruminants are less exposed to fasciolosis than buffaloes and cattle which provide major draft power in rice field farming activities. Both buffaloes and cattle have a wallowing nature that predisposes them to infection (Figure 3). Higher prevalence of fasciolosis was observed in animals more than 3 months old compared to other age groups simply because they are more often to eat or graze on farm grasses resulting to greater exposure to infection.

Infection with Fasciola spp. occurs when metacercariae are accidentally ingested on raw freshwater vegetation. The metacercariae migrates through the intestinal wall and peritoneal cavity to the liver where adults mature in the biliary ducts. Eggs pass through the bile ducts into the intestine where it then passes into the feces [284]. In humans, maturation from metacercariae into adult flukes takes approximately 3-4 months [285] (Figure 3).

Fasciolosis ranges in severity from a fatal disease in sheep to an asymptomatic infection in cattle $[286,287]$. The course of infection is usually determined by the number of ingested metacercariae. Fasciolosis can be classified into two such as (a) subacute and (b) chronic fasciolosis. Subacute fasciolosis cases have survival of 7-10 weeks with tremendous liver damage, however, the animal dies from hemorrhage and anemia, while chronic fasciolosis clinical manifestations includes anemia, wasting, submandibular edema, and decreased milk production, yet heavily infected cattle displays no clinical signs [286] (Table 7).

Most of F. gigantica and F. hepatica early studies assumed that infection and diseases caused by both fluke are similar. However, new studies on difference of F. hepatica and F. gigantica based on fluke biomass and average size, extent of liver damage, plasma glutamate dehydrogenase (GLDH) levels and gamma-glutamyl transpeptidases (GGT) response for the first 10 weeks of infection recognized $F$. hepatica develops more quickly than $F$. gigantica that results in an increase GLDH levels in plasma pointing out a greater damage to liver parenchyma [167] and an increased in the GGT levels at 10 weeks post-infection, indicating epithelial damage in the bile duct $[77,294]$.

The diagnosis of fasciolosis is imperative for planning treatment and the eradication program in an endemic area. Different diagnostic techniques are developed since then. Coproscopic detection through sedimentation technique is useful; however, there is concern in terms of sensitivity. Hence, immunodiagnostic techniques are recommended like enzyme-linked

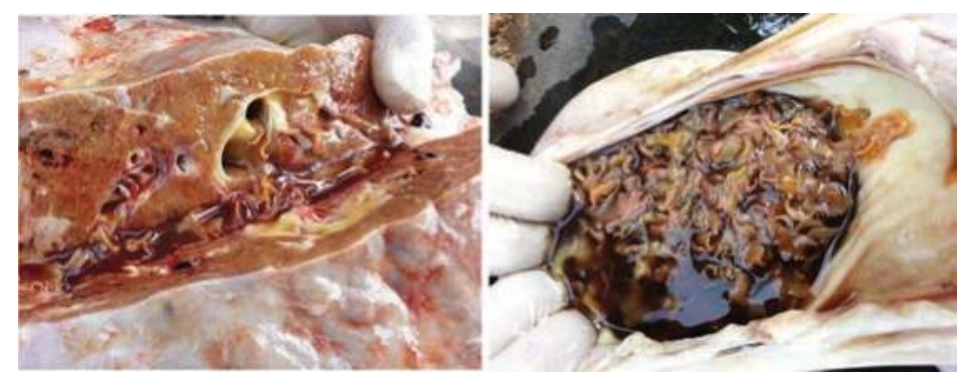

Figure 3. Presence of adult F. gigantica upon incision of the liver (left); a gall bladder of severely infected water buffalo filled with adult liver flukes (right) (photo from Philippine Carabao Center). 


\begin{tabular}{llll}
\hline Locality & Prevalence $(\%)$ & Technique & Authors \\
\hline Nigeria & $9.1^{4}, 12^{3}, 54.3^{2}$ & Sedimentation technique & Adediran et al. [288] \\
Pakistan & 5.68 & PCR & Ayaz et al. [289] \\
Philippines $^{1}$ & $95.33^{\mathrm{a}}$ and $96.00^{\mathrm{b}}$ & Quantitative PCR and FEA-SD & Gordon et al. [290] \\
Botswana & 0.09 & Post mortem examination & Mochankana and Robertson [291] \\
Vietnam & 23.4 & Microscopy examination & Nguyen et al. [292] \\
Egypt & 30.88 & Post mortem examination & Elshraway and Mahmound [293] \\
\hline
\end{tabular}

${ }^{1}$ Buffalo.

${ }^{2}$ Cattle.

${ }^{3}$ Sheep.

${ }^{4}$ Goat.

aPCR, polymerase chain reaction.

bFEA-SD, formalin-ethyl acetate sedimentation.

Table 7. Prevalence studies of Fasciolosis in different countries.

immunosorbent assay (ELISA). A recently developed technology is FgCL-3 ELISA which showed 100 and 97\% sensitivity under experimental and field situations [269]. Another platform is through molecular technique which is more specific than coproscopic and immunodiagnostic techniques. In Samar, Philippines, Gordon et al. [295] used quantitative real-time polymerase chain reaction in the detection of F. gigantica and it showed high it showed high prevalence of the disease.

Infected ruminants are usually treated with anthelminthic drugs like albendazole, triclabendazole and bromofenofos. But latest study showed that with the frequent usage of these common anthelmintic drugs, anthelmintic resistance may have developed in water buffaloes [296]. Other endeavor is the use of medicinal plant-like betel nut as dewormer in water buffaloes.

Fasciolosis control is a difficult and habitual task comprising of good and proper husbandry practices, good hygiene management (for animal excrements, waste waters, etc.) and effective integrated treatment and control for infected host and intermediate host, respectively. The use of predators (ducks and frogs) and molluscicides for control and possible elimination of the snail intermediate host is impossible as it is labor extensive, costly and may disturb the ecological balance in the area [297]. Vaccine development was vigorously pursued, however, despite persistent efforts, a vaccine with adequate protection against fasciolosis has not yet been developed to the point of commercialization [297].

\subsubsection{Schistosomiasis}

Schistosomiasis or bilharzia is one of the most prevalent parasitic diseases worldwide that currently infects over 200 million people in more than 76 countries, resulting in approximately 
25 million disability-adjusted life years lost $[298,299]$. The disease is caused by blood fluke species of the genus Schistosoma, namely S. mansoni, S. mekongi, S. haematobium, S. intercalatum and $S$. japonicum. Of particular importance is $S$. japonicum which is a zoonosis with a wide spectrum of definitive hosts (aside from humans), making control measures more complicated [298, 299].

Schistosomiasis japonica (term used for the disease caused by S. japonicum) is recognized as an important zoonotic disease in China, the Philippines and isolated pockets of Indonesia. Aside from established infection in human, S. japonicum can infect a variety of wild and domestic animals which have varying effects in transmission of infection to human. It is generally accepted that bovines, particularly water buffalo is considered the major reservoir of this human infection in China and the Philippines (Table 8) since they are naturally infected with schistosomes due to their wallowing behavior in marshes and deposit more eggs into the environment through their feces [295, 298, 299].

Although human infection caused by Schistosoma spp. can be reduced by treatment of praziquantel, control of schistosomiasis japonica still remains to be difficult, because of continuous transmission from shedder animals [245].Variable factors like the amount and quantity of host species, nonuniformity in irrigation management and practices and the possibility of genetic restrictions of infectivity to humans influenced and may cause complexity to the absolute importance of specific host species to human transmission by S. japonicum [299] (Table 8).

Animal schistosomiasis is traditionally diagnosed using direct coprological parasitologic techniques, for example, Kato-Katz technique and miracidia hatching. These simple and economical diagnostic techniques are very helpful in areas and cases with medium to very high infection intensity but has a drawback for low-level infections. Lately, polymerase chain reaction (PCR) platforms (e.g. convention and qualitative PCR) had been developed to amplify and detect the parasite DNA for the three zoonotic species of schistosoma [299].

Effective control measures of schistosomiasis japonica can be learned from China. Over the last 5 decades, China has remarkable schistosomias program achievements that drastically reduce the disease prevalence and morbidity, and the Chinese government is aiming to eradicate the disease in the country by 2020. The successful Chinese control action plan targets the importance on involvement on bovine considering efficacy of praziquantel, biosecurity measures on common grazing areas, mechanization as farm equipments and development of effective vaccine [301].

Schistosomiasis japonica has been eliminated in Japan and the coastal plains of China by a combination of medical treatment, health education, improved water quality and sanitation and snail control through environmental modification, molluscicide and new farming methods. In addition, several measures can be initiated such as mapping of the transmission patterns in humans and animals which can lead to a better understanding of transmission of schistosomiasis between different host species [302]. 


\begin{tabular}{llll}
\hline Locality & Prevalence (\%) & Technique & Authors \\
\hline Philippines & $\begin{array}{l}3.7^{\mathrm{c}}, 3.7^{\mathrm{d}}, \mathrm{0}^{\mathrm{e}} \text { and } \\
51.5^{\mathrm{a}}\end{array}$ & $\begin{array}{l}\text { Danish Bilharziasis Laboratory Technique, Kato-Katz } \\
\text { technique, Miracidia hatching and RT-PCR }\end{array}$ & Wu et al. [300] \\
Philippines & 51 & RT-PCR & Gordon et al. \\
& & [295] & Gordon et al. \\
Philippines & $87.50^{2, \mathrm{a}}$ and $77.08^{2, \mathrm{~b}}$ & RT-PCR and FEA-SD & [295] \\
& $80.00^{1, \mathrm{a} a}$ and $55.24^{1, \mathrm{~b}}$ & &
\end{tabular}

${ }^{1}$ Buffalo.

${ }^{2}$ Cattle.

aPCR, polymerase chain reaction.

bFEA-SD, formalin-ethyl acetate sedimentation.

'Danish Bilharziasis laboratory technique.

dKato-Katz technique.

${ }^{\mathrm{e}}$ Miracidia hatching.

Table 8. Prevalence studies of Schistosoma in the Philippines.

\section{Economic and public health impact}

From the diseases affecting water buffalo that were discussed, those that are zoonotic include leptospirosis, bovine tuberculosis, brucellosis, trypanosomiasis, cryptosporidiosis, fasciolosis and schistosomiasis. Also, the economic impact of these diseases in the water buffalo industry is alarming, particularly whose effects are unquantifiable since it is a neglected disease and highly prevalent in developing countries.

Bovine leptospirosis is an example of a zoonotic disease wherein the real economic hazard is quite difficult to be determined. In Argentina, for example, the reported losses from an outbreak is approximately US $\$ 150,000$ in regards of 100 calf deaths due to abortion, vaccination and treatment of the 1300 survivors along 1 year [65]. In France, the annual cost of leptospirosis in dairy cattle herds was estimated from US\$ 97 to 2611/aborted cow [303].

Another disease with limited information on its impact among livestock in endemic regions/ countries, particularly on its host population dynamics and demographics, economic losses and social impact on animal owners is Surra (T. evansi infection).

In the case of brucellosis, official estimates report annual losses of about $\$ 600$ million in Latin America due to bovine brucellosis [124]. The national program for the eradication of brucellosis in the US costs $\$ 3.5$ billion between 1934 and 1997. The losses due to reduced milk production and increased occurrence of miscarriages in 1952 were $\$ 400$ million [92]. Meanwhile, brucellosis as a zoonosis accounts for an annual occurrence of more than 500,000 cases [178, 238], which is considered the most common zoonosis worldwide. On the other hand, a national survey in India in bovines found a brucellosis prevalence of $5 \%$ in cattle and $3 \%$ in water buffaloes. The occurrence of the disease is usually high in organized farms (50\%) compared to the marginal herds $(10 \%)$ and this primarily associated with intensive farming practices in large organized animal farms [40]. 
The economic loss in Argentina due to BTb is at US\$ 63 million [304]. In the United States, cost/ benefit analysis of eradication showed an actual cost of US\$ 538 million between 1917 and 1992 (current programs cost approximately US\$3.5-4.0 million per year [94, 305]. Although cattle are the main reservoir of the bacterium, buffaloes are also infected by M. bovis, developing same clinical characteristics $[34,306,307]$. Buffalo embodies a significant economic activity in many countries such as Brazil where its herd of water buffalo (approximately 3 million animals) is the largest one of the Americas. They are mostly raised in rural areas and are great in adapting to various environmental conditions [87]. They also represent a potential zoonotic threat because they can be a source of infection to other animal species and to human beings [34, 130,307].

BVDV infection presents an economic concern since it affects both health and productivity of the herd. During outbreaks of acute BVD, losses were estimated to be $\$ 50-\$ 100$ per cow in the herd. In Canada, were in severe acute BVD was reported around 1998, the estimated losses was $\$ 40,000-\$ 100,000$ per herd, or $\$ 400$ per cow in the each herd [164].

Fasciola spp. infection can also infect human and is classified as a neglected tropical disease. It was recorded that global losses incidental to fasciolosis were estimated over US \$3200 million per year [4]. Species-wise prevalence of fasciolosis varies in different regions, globally. In India, goats were more infected than buffaloes [308]. Also, overall caprine fasciolosis was observed to be $20.75 \%$ in Bangladesh [309]. Recently, in Corrientes, Argentina, appearance of fasciolosis was observed in different buffalo populations showing $28.5 \%$ prevalence rate [310]. In the provinces of Punjab (30.5\%) and Sidh (42.06\%), Pakistan, there was a remarkably high prevalence of fasciolosis in buffalo [286, 311]. Likewise, in Nepal, there was above $50 \%$ prevalence rate in large ruminants. Meanwhile, in South East Asia, China and Poland, had a prevalence rate of $27.7 \%$ [312], 34.8\% and 32\% [301]. A coproscopy examination in Iringa district, Tanzania, reported that overall prevalence of fasciolosis in traditional, large scale dairy and small scale dairy cattle was $63.8,46.2$ and $28.4 \%$, respectively.

In the case of schistosomiasis, three recent interventional studies strongly support the contribution of water buffaloes to human transmission along the lake and marshlands region of China. In two studies, S. japonicum reinfection of humans were $48-49 \%$ lower than praziquantel medicated farm animals and individuals. A result from an operational research suggests that improvement in hygiene and removal of bovine from an infected area will likely decrease the human infection by $88 \%$ than the control areas. An analytical modeling of intra-species transmission dynamics from different ecological settings in China indicates that 39-99\% of zoonosis of Schistosomiasis japonicum infection came from buffaloes [299].

\section{Conclusion}

In conclusion, this review demonstrated the importance of water buffalo as a progressive livestock industry in several countries worldwide, harnessing its adaptability in tropical and subtropical climate without affecting its reproductive performance. Also, several infectious diseases affecting this animal were discussed that have an enormous negative economic impact in the industry as well as its threat to human health. Knowledge on these common diseases in water buffaloes and its management will be beneficial to veterinarians and farmers 
in preventing the occurrence of those infectious diseases. In addition, limited studies and published articles on infectious diseases in water buffalo were available, since it is believed that diseases in cattle are similar to that of water buffalo. This should be changed because both species behave differently in such diseases. Aside from the conventional control and prevention methods against the discussed infectious diseases, development of a simpler and practical farm management practices are needed. Lastly, more studies should be conducted, especially in areas where water buffalo is the main livestock animal in order to utilize the full potential of the animal and uplift the water buffalo industry.

\section{Author details}

Marvin A. Villanueva ${ }^{1,2}$, Claro N. Mingala ${ }^{1,2}$, Gabriel Alexis S. Tubalinal ${ }^{2}$, Paula Blanca V. Gaban², Chie Nakajima ${ }^{3,4}$ and Yasuhiko Suzuki ${ }^{3,4 *}$

*Address all correspondence to: suzuki@czc.hokudai.ac.jp

1 Biosafety and Environment Section, Philippine Carabao Center National Headquarters and Gene Pool, Science City of Muñoz, Nueva Ecija, Philippines

2 Livestock Biotechnology Center, Philippine Carabao Center National Headquarters and Gene Pool, Science City of Muñoz, Nueva Ecija, Philippines

3 Division of Bioresources, Hokkaido University Research Center for Zoonosis Control, Sapporo, Hokkaido, Japan

4 The Global Station for Zoonosis Control, Hokkaido University Global Institution for Collaborative Research and Education, Sapporo, Japan

\section{References}

[1] Ali S, Ali Q, Melzer F, Khan I, Shamin A, Neubauer H, Jamal SM. Isolation and identification of bovine Brucella isolates from Pakistan by biochemical test and PCR. Tropical Animal Health and Production. 2013. DOI: 10.1007/s11250.013-0448.6

[2] dos Santos LS, Sa JC, dos Santos Ribeiro DL, Chaves NP, da Silva Mol JP, Santos RL, da Paixao TA, de Carvalho Neta AV. Detection of Brucella spp. infection through serological, microbiological, and molecular methods applied to buffaloes in Maranhao state, Brazil. Tropical Animal Health and Production. 2017. DOI: 10.1007/s11250-017-1238-3

[3] Nardi Junior G, Ribeiro MG, Jorge AM, Megid J, Silva LMP. Serological profile of buffalo (Bubalus bubalis) female calves vaccinated with standard Brucella abortus strain 19 using rose Bengal, 2-mercaptoethanol and complement fixation test. Biologicals. 2012;40:158-161

[4] Sharma N, Singh NK, Bhadwal1 MS. Relationship of somatic cell count and mastitis: An overview. Asian-Australasian Journal of Animal Sciences. 2011;24(3):429-438 
[5] Yang DY, Liu L, Chen X, Speller CF. Wild or domesticated: DNA analysis of ancient water buffalo remains from north China. Journal of Archaeological Science. 2008;35:2778-2785

[6] Paulin LM, Ferreira Neto JS. Artigo de revisão: Brucelose em búfalos (in Portuguese, with English abstract). Arquivos do Instituto de Biológia. 2008;75:389-401

[7] Fosgate GT, Diptee MD, Ramnanan A, Adesiyun AA. Brucellosis in domestic water buffalo (Bubalus bubalis) of Trinidad and Tobago with comparative epidemiology to cattle. Tropical Animal Health and Production. 2011;43:1479-1486. DOI: 10.1007/s11250011-9846-9

[8] Adler B. Leptospira and Leptospirosis. Verlag Berlin Heidelberg: Springer; 2015. p. 384

[9] Favero JF, de Araújo HL, Lilenbaum W, Machado G, Tonin AA, Baldissera MD, Stefani LM, Da Silva AS. Bovine leptospirosis: Prevalence, associated risk factors for infection and their cause-effect relation. Microbial Pathogenesis. 2017;107:149-154

[10] Brown RA, Blumerman S, Gay C, Bolin C, Duby R, Baldwin CL. Comparison of three different leptospiral vaccines for induction of a type 1 immune response to Leptospira borgpetersenii serovar hardjo. Vaccine. 2003;21:4448-4458

[11] Higgins RJ, Harbourne JF, Little TWA, Stevens AE. Mastitis and abortus in dairy cattle associated with leptospira of the serotype hardjo. The Veterinary Record. 1980;107:307-310

[12] Dorjee S, Heuer C, Jackson R, West DM, Collins-Emerson JM, Midwinter AC, Ridler AL. Prevalence of pathogenic Leptospira spp. in sheep in a sheep-only abattoir in New Zealand. New Zealand Veterinary Journal. 2008;56(4):164-170. DOI: 10.1080/00480169.2008.36829

[13] Leon LL, Garcia RC, Diza CO, Valdez RB, Carmona GC, Velazquez BL. Prevalence of leptospirosis in dairy cattle from small rural production units in Toluca Valley, state of Mexico. Annals of the New York Academy of Sciences. 2008;1149:292-295. DOI: 10.1196/ annals.1428.002

[14] Gamage CD, Koizumi N, Muto M, Nwafor-Okoli C, Kurukurusuriya S, Rajapakse JR, Kularatne SA, Kanda K, Lee RB, Obayashi Y, Watanabe H, Tamashro H. Prevalence and carrier status of leptospirosis in smallholder dairy cattle and peridomestic rodents in Kandy, Sri Lanka. Vector Borne and Zoonotic Diseases. 2011;11(8):1041-1047. DOI: 10.1089/vbz.2010.0153

[15] Suepaul SM, Carrington CV, Campbell M, Borde G, Adesiyun AA. Seroepidemiology of leptospirosis in livestock in Thailand. Tropical Animal Health and Production. 2011;43(2):367-375. DOI: 10.1007/s11250-010-9698-8

[16] Ngbede EO, Raji MA, Kwanashie CN, Okolocha EC, Gugong VT, Hambolu SE. Serological prevalence of leptospirosis in cattle slaughtered in the Zango abattoir in Zaria, Kaduna state, Nigeria. Veterinaria Italiana. 2012;48(2):179-184

[17] Atherstone C, Picozzi K, Kalema-Zikusoka G. Seroprevalence of Leptospira hardjo in cattle and African buffaloes in southwestern Uganda. The American Journal of Tropical Medicine and Hygiene. 2014;90(2):288-290. DOI: 10.4269/ajtmh.13-0466 
[18] Rypula K, Ploneczka-Janeckzo K, Bieroweic K, Chorbinski P, Pearce MC, Lesiak M. Prevalence of antibodies to Leptospira hardjo in bulk tank milk from unvaccinated dairy herds in the south-west region of Poland. Berliner Und Munchener Tierarztliche Wochenschrift. 2014;127(506):247-250

[19] de CarvalhoSM, Mineiro AL, Castro V, Genovez ME, AzevedoSS, Costa FA. Leptospirosis seroprevalence and risk factors for sheep in Maranhao state, Brazil. Tropical Animal Health and Production. 2014;46(2):491-494. DOI: 10.1007/s11250-013-0505-1

[20] Lucchese L, Benkirane A, Hakimi I, El Idrissi A, Natale A. Seroprevalence stuy of the main causes of abortion in dairy cattle in Morocco. Veterinaria Italiana. 2016;52(1):13-19. DOI: $10.12834 /$ VetIt.388.1813.1

[21] Suwancharoen D, Limlertvatee S, Chetiyawan P, Tongpan P, Sangkaew N, Sawaddee Y, Inthakan K, Wiratsudakul AA. Nationwide survey of pathogenic leptospires in urine of cattle and buffaloes by loop-mediated isothermal amplification (LAMP) method in Thailan, 2011-2013. The Journal of Veterinary Medical Science. 2016;789:1495-1500

[22] Villanueva MA, Mingala CN, Balbin MM, Nakajima C, Isoda N, Suzuki Y, Koizumi N. Molecular epidemiology of pathogenic Leptospiraa spp. among large ruminants in the Philippines. The Journal of Veterinary Medical Science. 2016;78(11):1649-1655

[23] Flores BJ, Perez-Sanchez T, Fuertes H, Sheleby-Elias J, Muzquiz JL, Jiron W, Duttmann C, Halaihel N. A cross-sectional epidemiology study of domestic animals related to human leptospirosis cases in Nicaragua. Acta Tropica. 2017;170:79-84. DOI: 10.1016/j. actatropica.2017.02.031

[24] Campos AP, Miranda DFH, Rodriguez HWS, Da Silva Carneiro Lustosa M, Martins GHC, Mineiro ALBB, Castro V, Azevedo SS, de Sousa Silva SMM. Seroprevalence and risk factors for leptospirosis in cattle, sheep, and goats at consorted rearing from the state of Piaui, northeastern Brazil. Tropical Animal Health and Production. 2017;49(5):899907. DOI: 10.1007/s11250-017-1255-2

[25] Olmo L, Dye MT, Reichel MP, Young JR, Nampanya S, Khousny S, Thomson PC, Windsor PA, Bush RD. Investigation of infectious pathogens of large ruminants: Are neosporosis, brucellosis leptospirosis and BVDV of relevance in Lao PDR? Acta Tropica. 2018;177:118-126. DOI: 10.1016/j.actatropica.2017.10.007

[26] Ellis WA, O'Brien JJ, Bryson DG, Mackie DP. Bovine leptospirosis: Some clinical features of serovar hardjo infection. The Veterinary Record. 1985;117:101-104

[27] Ellis WA, Montgomery J, Cassells JA. Dihydrostreptomycin treatment of bovine carriers of Leptospira interrogans serovar Hardjo. Research in Veterinary Science. 1985;39:292-295

[28] Dhaliwal GS, Murray RD, Ellis WA. Reproductive performance of dairy herds infected with Leptospira interrogans serovar hardjo relative to the year of diagnosis. The Veterinary Record. 1996;138:272-276

[29] Hathaway SC, Little TWA. Epidemiological study of Leptospira hardjo infection in second calf dairy cows. The Veterinary Record. 1983;112:215-218 
[30] Bharti AR, Nally JE, Ricaldi JN, Matthias MA, Diaz MM, Lovett MA, Levett PN, Gilman RH, Willig MR, Gotuzzo E, Vinetz JM. Leptospirosis: A zoonotic disease of global importance. The Lancet Infectious Diseases. 2003;3(12):757-771

[31] Dubey JP, Buxton D, Wouda W. Pathogenesis of bovine neosporosis. Journal of Comparative Pathology. 2006;134:267-289

[32] Dubey JP, Schares G. Diagnosis of bovine neosporosis. Veterinary Parasitology. 2006;140:1-34

[33] El-Khodery SA, Osman SA. Cryptosporidiosis in buffalo calves (Bubalus bubalis): Prevalence and potential risk factors. Tropical Animal Health and Production. 2008;40:419-426

[34] Medeiros LS, Marassi CD, Figueiredo EES, Lilenbaum W. Potential application of new diagnostic methods for controlling bovine tuberculosis in Brazil. Brazilian Journal of Microbiology. 2010;41:531-541

[35] Santín M, Fayer R. Intragenotypic variations in the Cryptosporidium spp. cervine genotype from sheep with implications for public health. Journal of Parasitology. 2007;93:668-672

[36] Hartskeerl RA, Collares-Pereira M, Ellis WA. Emergence, control and re-emerging leptospirosis: Dynamics of infection in the changing world. Clinical Microbiology and Infection. 2011;17:494-501

[37] Ellis WA. Leptospirosis as a cause of reproductive failure. The Veterinary Clinics of North America. Food Animal Practice. 1994;10:463-478

[38] Sebastian M, Giles R, Roberts J, Poonacha K, Harrison L, Donahue J, Benirschke K. Funisitis associated with leptospiral abortion in an equine placenta. Veterinary Pathology. 2005;42:659-662

[39] Levett PN. Leptospirosis. Clinical Microbiology Reviews. 2001;14:296-328

[40] Vijayachari P, Sugunan AP, Umapathi T, Sehgal SC. Evaluation of dark ground microscopy as a rapid diagnostic procedure in leptospirosis. The Indian Journal of Medical Research. 2001a;114:54-58

[41] Mondal A, Chakravarti S, Majee SB, Bannalikar AS. Detection of picobirnavirus and rotavirus in diarrhoeic faecal samples of cattle and buffalo calves in Mumbai metropolis, western India. Veterinaria Italiana. 2013 Oct-Dec;49(4):357-360

[42] Ross L, Jakowski R, Bolin C, Kiupel M. Retrospective immunohistochemical detection of Leptospira in dogs with renal pathology. International Journal of Applied Research in Veterinary Medicine. 2011;9(4):324-331

[43] Ellis WA, O'Brien JJ, Neill SD, Ferguson HW, Hanna J. Bovine leptospirosis: Microbiological and serological findings in aborted fetuses. The Veterinary Record. 1982;110:147-150

[44] Ellis WA, O’Brien JJ, Neill SD, Hanna J. Bovine leptospirosis:Serological findings in aborting cows. The Veterinary Record. 1982;110:178-180

[45] Nervig RM, Garrett LA. Use of furosemide to obtain bovine urine samples for leptospiral isolation. American Journal of Veterinary Research. 1979;40:1197-1200 
[46] Ellinghausen HC. Growth temperatures, virulence, survival, and nutrition of leptospires. Journal of Medical Microbiology. 1973;6:487-497

[47] Alt DP, Bolin CA. Preliminary evaluation of antimicrobial agents for treatment of Leptospira interrogans serovar Pomona infection in hamsters and swine. American Journal of Veterinary Research. 1996;57(59-62):24

[48] Alt DP, Zuerner RL, Bolin CA. Evaluation of antibiotics for treatment of cattle infected with Leptospira borgpetersenii serovar Hardjo. Journal of the American Veterinary Medical Association. 2001;219:636-639

[49] Cortese VS, Behan S, Galvin JE, Penka DR, Ramsey D, Bryson WL, Lucas MJ. Evaluation of two antimicrobial therapies in the treatment of Leptospira borgpetersenii serovar hardjo infection in experimentally infected cattle. Veterinary Therapeutics. 2007;8(3):201-208

[50] Smith CR, Corney BG, McGowan MR, McClintock CS, Ward W, Ketterer PJ. Amoxycillin as an alternative to dihydrostreptomycin sulphate for treating cattle infected with Leptospira borgpetersenii serovar hardjo. Australian Veterinary Journal. 1997;75(11):818-821

[51] Hodges RT, Thomson J, Towsend KG. Leptospirosis in pigs: The effectiveness of streptomycin in stopping leptospiruria. New Zealand Veterinary Journal. 1979;27:124-126

[52] Bolin CA. Clinical signs, diagnosis, and prevention of leptospirosis in cattle. Cattle Practice. 2001;9(4):267-273

[53] Bolin CA. Diagnosis of leptospirosis: A reemerging disease of companion animals. Seminars in Veterinary Medicine and Surgery (Small Animal). 1996;11:166-171

[54] Rinehart CL, Zimmerman RE, Buterbaugh RA, Jolie RA, Chase CCL. Efficacy of vaccination of cattle with the Leptospira interrogans serovar hardjo type hardjoprajitno component of a pentavalent Leptospira bacterin against experimental challenge with Leptospira borgpetersenii serovar hardjo type hardjo-bovis. American Journal of Veterinary Research. 2012;73:735-740

[55] Wiker HG. MPB70 and MPB83-major antigens of Mycobacterium bovis review. Scandinavian Journal of Immunology. 2009;69:492-499

[56] Abubakar M, Javed Arshed M, Hussain M, Ethisham-ul-Haq, Ali Q. Serological evidence of Brucella abortus prevalence in Punjab, province, Pakistan - A cross-sectional study. Transboundary and Emerging Diseases. 2010. DOI: 10.1111/j/1865-1682.2010.01171.x

[57] Wareth G, Hikal A, Refai M, Melzer F, Roesler U, Neubauer H. Animal brucellosis in Egypt. Journal of Infection in Developing Countries. 2014;8(11):1365-1373. DOI: 10.3855/jidc.4872

[58] Gumaa MM, Osman HM, Omer MM, El Sanousi EM, Godfroid J, Ahmed AM. Seroprevalence of brucellosis in sheep and isolation of Brucella abortus biovar 6 in Kassala state, eastern Sudan. Revue Scientifique et Technique. 2014;33(3):957-965

[59] Bamaiyi PH, Hassan L, Khairani-Bejo S, Zainal Abidin M, Ramlan M, Adzhar A, Abdullah N, Hamidah NH, Norsuhanna MM, Hashim SN. The prevalence and distribution of Brucella melitensis in goats in Malaysia from 2000 to 2009. Preventive Veterinary Medicine. 2015;119(3-4):232-236. DOI: 10.1016/j.prevetmed.2015.02.001 
[60] Aslan ME, Azkur AK, Gazyagci S. Epidemilogy and genetic characterization of BVDV, BHV-1, BHV-4, BHV-5 and Brucella spp. infection in cattle in Turkey. The Journal of Veterinary Medical Science. 2015;77(11):1371-1377. DOI: 10.1292/jvms.14-0657

[61] Aznar MN, Linares FJ, Cosentino B, Sago A, La Sala L, Leon E, Duffy S, Perez A. Prevalence and spatial distribution of bovine brucellosis in san Luiz and la pampa, Argentina. BMC Veterinary Research. 2015;11:209. DOI: 10.1186/s12917-015-0535-1

[62] Sintayehu G, Melesse B, Abayneh D, SInatayehu A, Maleku S, Alehegne W, Mesfin S, De Blas I, Casal J, Allepuz A, Martin-Valls G, Africa T, Abera K. Epidemiological survey of brucellosis in sheep and goats in selected pastoral and agro-pastoral lowlands of Ethiopia. Revue Scientifique et Technique. 2015;34(3):881-893

[63] Hegazy Y, Elmonir W, Abdel-Hamid NH, Elbauomy EM. Seroprevalence and "knowledge, attitudes and practices" (KAPs) survey of endemic ovine brucellosis in Egpyt. Acta Veterinaria Scandinavica. 2016;58:1. DOI: 10.1186/s13028-015-0183-2

[64] Rajala EL, Grahn C, Ljung I, Sattorov N, Bogvist S, Magnusson U. Prevalence and risk factors for Brucella seropositivity among sheep and goats in a pre-urban region of Tajikistan. Tropical Animal Health and Production. 2016;48(3):553-558. DOI: 10.1007/s11250-015-0992-3

[65] Draghi MG, Brihuega B, Benítez D, Sala JM, Biotti GM, Pereyra M, Homse A, Guariniello L. Leptospirosis outbreak in calves from Corrientes Province, Argentina. Revista Argentina de Microbiología. 2011;43:42-44

[66] Akinseye VO, Adesokan HK, Ogugua AJ, Adedoyin FJ, Otu PI, Kwaghe AV, Kolawole NO, Okoro OJ, Agada CA, Tade AO, Faleke OO, Okeke AL, Akanbi IM, Ibitoye MM, Dipeolu MO, Dale EJ, Lorraine P, Taylor AV, Awosanya EA, Cadmus EO, Stack JA, Cadmus SI. Sero-epidemiological survey and risk factors associated with bovine bruceloosis among slaughtered cattle in Nigeria. The Onderstepoort Journal of Veterinary Research. 2016;83(1):a10002. DOI: 10.4102/ojvr.v83i1.1002

[67] Douangngeun B, Theppangna W, Soukvilay V, Senaphanh C, Phithacthep K, Phomhaksa S, Yingst S, Lombardini E, Hansson E, Selleck PW, Blacksell SD. Seroprevalence of Q fever, brucellosis, and bluetongue in selected provinces in Lao People's Democratic Republic. The American Journal of Tropical Medicine and Hygiene. 2016;95(3):558-561. DOI: 10.4269/ajtmh.15-0913

[68] Pathak AD, Dubal ZB, Karunakaran M, Doijad SP, Roarane AV, Dhuri RB, Bale MA, Chakurkar EB, Kalorey DR, Kurkure NV, Barbuddhe SB. Apparent seroprevalence, isolation and identification of risk factors for brucellosis among dairy cattle in Goa, India. Comparative Immunology, Microbiology and Infectious Diseases. 2016;47:1-6. DOI: 10.1016/j.cimid.2016.05.004

[69] Miller R, Nakavuma JL, Ssajjakambwe P, Vudriko P, Musisi N, Kaneene JB. The prevalence of brucellosis in cattle, goats and humans in rural Uganda: A comparative study. Transboundary and Emerging Diseases. 2016;63(6):e197-e210. DOI: 10.1111/tbed.12332

[70] Kanoute YB, Gragnon BG, Schindler C, Bonfoh B, Schelling E. Epidemiology of brucellosis, $\mathrm{Q}$ fever, and Rift Valley fever at the human and livestock interface in northern cote d'Ivoire. Acta Tropica. 2017;165:66-75. DOI: 10.1016/j/actatropica.2016.02.012 
[71] Roman-Ramirez DL, Martinez-Herrera DI, Villagomez-Cortes JA, Peniche-Cardena AE, Morales-Alvarez, and Flores-Castro, R. Epidemiology of caprine brucellosis in the central zone of the state of Veracruz. Gaceta Médica de México. 2017;153(1):26-30

[72] Ali S, Akther S, Neubauer H, Melzer F, Khan I, Abatij EN, El-Adawy H, Irfan M, Muhammad A, AKbar MW, Umar S, Ali Q, Igbal MN, Mahmood A, Ahmed H. Seroprevalence and risk factors associated with bovine brucellosis in the Potohar plateau, Pakistan. BMC Research Notes. 2017;10(1):73. DOI: 10.1186/s13104-017-2394-2

[73] Hernandez-Mora G, Ruiz-Villalobos N, Bonilla-Montoya R, Romero-Zuniga JJ, JimenezArias J, Gonzalez-Barrientos R, Barquero-Calvo E, Chacon-Diaz C, Rojas N, ChavesOlarte E, Guzman-Verri C, Moreno E. Epidemiology of bovine brucellosis in Costa Rica: Lessons learned from failures in the control of the disease. PLoS One. 2017;12(8):e0182380. DOI: 10.1371/journal.pone.0182380

[74] Kardjadj M. Did Rev-1 small ruminants vaccination helped improve cattle brucellosis prevalence status in Algeria? Tropical Animal Health and Production. 2017;49(8):17831785. DOI: $10.1007 / \mathrm{s} 11250-017-1370-0$

[75] Ali S, Akhter S, Neubauer H, Melzer F, Khan I, Abatih EN, El-Adawy H, Irfan M, Muhammad A, Akbar MW, Umar S, Ali Q, Iqbal MN, Mahmood A, Ahmed H. Seroprevalence and risk factoes associated with bovine brucellosis in the Potohar plateau, Pakistan. BMC Research Notes. 2017

[76] Chaves NP, Bezerra DC, Santos LS, Sá JS, Santos HP, Pereira HM. Intercorrência entre leucose enzoótica e brucelose em búfalos (Bubalus bubalis) em sistema de produção extensivo. Pesquisa Veterinaria Brasileira. 2012;32(2):131-134

[77] Martinez-Valladares M, Famularo MR, Fernandez-Pato N, Castañon-Ordoñez L, Cordero-Perez C, Rojo-Vazquez. Activity of nytroxinil against Fasciola hepatica resistant to triclabendazole in a naturally infected sheep flock. Parasitology Research. 2010;107:1205-1211

[78] Shome R, Filia G, Padmashree BS, Krithiga N, Shay S, Triveni K, Shome BR, Mahajan V, Singh A, Rahman H. **evaluation of lateral flow assay as a field test for investigation of brucellosis outbreak in an organized buffalo farm: A pilot study. Veterinary World. 2015. EISSN: 2231-0916

[79] Silva JB, Rangel CP, da Fonseca AH, deMorais E, Vinhote WM, da Silva Lima DH, da Silva e Silva N, Barbosa JD. Serological survey and risk factors for brucellosis in water buffaloes in the state of Pará, Brazil. Tropical Animal Health and Production. 2014;46(2):385-389

[80] Sousa MGS, Brito MF, Ubiali DG, Fonseca AA Jr, Silva JB, Reis AS, Oliveira CMC, Barbosa JD. Detecção de Brucella abortus em linfonodos de búfalas (Bubalus bubalis) em diferentes fases da gestação. Pesquisa Veterinaria Brasileira. 2015;35(12):951-955

[81] Poester FP, Samartino LE, Santos RL. Pathogenesis and pathobiology of brucellosis in livestock. Revue Scientifique et Technique - Office International des Épizooties. 2013;32:105-115 
[82] Mohan RN. Diseases and parasites of buffaloes. The Veterinary Bulletin. 1968;38(10): 647-659

[83] Polding JB. Brucellosis in India. Indian Journal of Veterinary Science Animal Husbandary. 1947;17:147-155

[84] Sewell MMH, Brocklesby DW. Animal Diseases in the Tropics. London: Bailliere Tindall; 1990. p. 385

[85] Comerci D, Altabe S, de Mendoza D. Brucella abortus synthesizes phosphatidylcholine from choline provided by the host. Journal of Bacteriology. 2006;188:1929-1934

[86] Adesiyum AA, Fosgate GT, Seebaransingh R, Brown G, Stoute S, Stewart-Johnson A. Virulence of Brucella abortus isolated from cattle and water buffalo. Tropical Animal Health and Production. 2011;43:13-16. DOI: 10.1007/s/11250-010-9679-y

[87] Brasil, 2004. Empresa Brasileira de Pesquisa Agropecuária -EMBRAPA. Brucelose e Tuberculose bovina: epidemiologia, controle e diagnóstico. Embrapa informação tecnológica, Brasília, 94 pp

[88] Molnár L, Molnár E, Lima ESC, Dias HLT. Avaliação de seis testes sorológicos no diagnóstico da brucelose bubalina. Pesquisa Veterinaria Brasileira. 2002;22(2):41-44

[89] Borrielo G, Peletto S, Lucibell MG, Acutis PL, Ercolini D, Gallero G. Link between geographical origin and occurrence of Brucella abortus biovars in cow and water buffalo herds. Applied and Environmental Microbiology. 2013;79(3):1039-1043

[90] Capparelli R, Alfano F, Amoroso MG, Borriello G, Fenizia D, Bianco M, Roperto S, Roperto F, Iannelli D. Protective effect of the Nramp1 BB genotype against Brucella abortus in the water buffalo (Bubalus bubalis). Infection and Immunity. 2007;75:988-996

[91] Capparelli R, Partalo M, Amoroso MG, Roperto S, Marabelli R, Roperto F, Iannelli D. Mannose-binding lectin haptotypes influence Brucella abortus infection in the water buffalo (Bubalus bubalis). Immunogentics. 2008;60:157-165

[92] da Silva JB, Rangel CP, de Fonseca AH, de Morais E, Vinhote WMS, da Silva Lima DH, da Silva e Silva N, Barbosa JD. Serological survey and risk factors for brucellosis in water buffaloes in the state of Para, Brazil. Tropical Animal Health and Production. 2013, 2014;46(2):385-389

[93] de Nardi Júnior G, Ribeiro MG, Paulin L, Jorge AM. Brucelose em bubalinos: Uma revisão com ênfase ao sorodiagnóstico oficial (in Portuguese, with English abstract). Veterinaria e Zootecnia. 2012;19:142-156

[94] Hassan AS, Farba SM, GUmel AB, Lubuma JM-S. Dynamics of mycobacterium and bovine tuberculosis in human-buffalo population. Computational and Mathematical Methods in Medicine. 2014. DOI: 10.1155/2014/912306

[95] Huang ZYX, De Boer WF, Van Langevelde F, Xu C, Ben Jebara K, Berlinger F, HHT P. Dilution effect in bovine tuberculosis: Risk factors for regional disease occurrence in Africa. Proceedings of The Royal B Society. 2013 
[96] Khattak I, Mushtaq MH, MUD A, Khan MS, Chaudhry, Ssique U. Risk factors associated with Mycobacterium bovis skin positivity in cattle and buffalo in Peshawar, Pakistan. Tropical Animal Health and Production. 2015. DOI: 10.1007/s11250-015-0976-3

[97] Roex Nl, Koets AP, van Helden PD, and Hoal EG (2013). Gene polymorphisms in African buffalo associated with susceptibility to bovine tuberculosis infection. PLoS One 8(5):e64494

[98] Renwick AR, White PCL, Bengis RG. Bovine tuberculosis in southern Africa wildlife: A multispecies host-pathogen system. Epidemiology and Infection. 2007;135:529-540. DOI: $10.1017 /$ S0950268806007205, 10.1017/S0950268806007205

[99] Roche B, Dobson AP, Guegan JF, Rohani P. Linking community and disease ecology: The impact of biodiversity on pathogen transmission. Philosophical Transactions of the Royal Society B. 2012;367:2807-2813. DOI: 10.1098/rstb. 2011.0364

[100] Corner LAL. The role of wild animal populations in the epidemiology of tuberculosis in domestic animals: How to assess the risk. Veterinary Microbiology. 2006;112:303-312. DOI: 10.1016/j.vetmic.2005.11.015

[101] Oliveira I, Melo H, Câmara A, Dias R, Soto-Blanco B. Prevalência de tuberculose no rebanho bovino de Mossoró, Rio Grande do Norte. Brazilian Journal of Veterinary Research and Animal Science. 2007;44:395-400

[102] Etter E, Donado P, Jori F, Caron A, Goutard F, Roger F. Risk analysis and bovine tuberculosis, a re-emerging zoonosis. Annals of the New York Academy of Sciences. 2006;1081:61-73

[103] Javed MT, Shahid AL, Farooqi FA, Akhtar M, Cardenas GA, Wasiq M, Cagiola M. Association of some of the possible risk factors with tuberculosis in water buffalo around two cities of Punjab Pakistan. Acta Tropica. 2010;115:242-247

[104] LoBue PA, Enarson DA, Thoen CO. Tuberculosis in humans and animals: An overview. The International Journal of Tuberculosis and Lung Disease. 2010;14:1075-1078

[105] Kalema-Zikusoka G, Bengis RG, Michel AL, Woodford MH. A preliminary investigation of tuberculosis and other diseases in Africa buffalo (Syncerus caffer) in queen Elizabeth National Park, Uganda. Onderteporrt J. Veterinary Research. 2005;72(2):145-151

[106] Vongxay K, Conlan JV, Khousny S, DOrny P, Fenwick S, Thompson RC, Blacksell SD. Seroprevalence of major bovine-associated zoonotic infectious diseases in the Lao People's Democratic Republic. Vector Borne and Zoonotic Diseases. 2012;12(10):861866. DOI: $10.1089 /$ vbz.2011.0850

[107] Barbosa JD, da Silva JB, Rangel CP, da Fonseca AH, Silva NS, Bomjardim HA, Freitas NF. Tuberculosis prevalence and risk factors for water buffalo in Para, Brazil. Tropical Animal Health and Production. 2014;46(3):513-517. DOI: 10.1007/s11250-013-0521-1

[108] Linderot de Cardona K, De Gracia Scanapeico A, Braun PG. First results on small ruminant brucellosis and tuberculosis and caprine arthritis-encephalitis in El Salvador. Tropical Animal Health and Production. 2016;48(5):1083-1087 
[109] Amemor EA, Sackey SO, Yebuah N, Folitse RD, Emikpe BO, Afari E, Wurapa F, Ohuabunwo C, Addo K, Mensah D, Gaglo E, Mark-Hansen, Johnson S, Tasaiame W, Amedzovor D, Nkunafa D, Bonsu F. The prevalence of tuberculosis in cattle and their handlers in north Tongu, Volta region, Ghana. African Journal of Infectious Diseases. 2016;11(1):12-17. DOI: 10.21010/ajid.v11i1.2

[110] Ghebremariam MK, Rutten VP, Vernooij JC, Uqbazghi K, Tesfaalem T, Butsuamlak T, Idris AM, Nielen M, Michel AL. Prevalence and risk factors of bovine tuberculosis in dairy cattle in Eritrea. BMC Veterinary Research. 2016;12:80. DOI: 10.1186/ s12917-016-0705-9

[111] Muñoz-Mendoza M, Romero B, De Cerro A, Gortazar C, Garcia-Marin JF, Menendez S, Mourelo J, de Juan L, Saez JL, Delahay RJ, Balseiro A. Sheep as a potential source of bovine TB: Epidemiology, pathology and evaluation of diagnostic techniques. Transboundary and Emerging Diseases. 2016;63(6):635-646. DOI: 10.1111/tbed/12325

[112] Egbe NF, Muwonge A, Ndip L, Kelly RF, Sander M, Tanya V, Ngwa VN, Handel IG, Novak A, Ngandalo R, MAzeri S, Morgan KL, Asuguo A, and de C Bronsvoort BM. (2017). Molecular epidemiology of Mycobacterium bovis in Cameroon. Scientific Reports 7(1):4652. doi: 10.1038/s41598-017-04230-6

[113] Bhembe NL, Jaja IF, Nwodo UU, Okoh AL, Green E. Prevalence of tuberculous lymphadenitis in slaughtered cattle in eastern cape, South Africa. International Journal of Infectious Diseases. 2017;61:27-37. DOI: 10.1016/j/ijid.2017.05.005

[114] Luboya LW, Malangu M, Kaleka M, Ngulu N, Nkokele B, Maryabo K, Pourrut X, Vincent T, Gonzalez JP. An assessment of caprine tuberculosis prevalence in Lubumbashi slaughterhouse, Democratic Republic of Congo. Tropical Animal Health and Production. 2017;49(4):875-878. DOI: 10.1007/s11250-017-1252-5

[115] Alfano F, Peletto S, Lucibelli MG, Borriello G, Urciuolo G, Maniaci MG, Desiato R, Tarantino M, Barone A, Pasquali P, Acutis PL, Gallero G. Identification of single nucleotide polymorphisms in toll-like receptor candidate gens associated with tuberculois infection in water buffalo (Bubalis bubalis). BMC Genetics. 2014;25(139)

[116] Akhtar F, Javed MT, Rehman A, Khan MN, Akhtar P, Hussain SM, Aslam MS, Kausar $\mathrm{R}$, Qamar M, Cagiola M. The use of PCR technique in the identification of mycobacterium species responsible for bovine tuberculosis in cattle and buffaloes in Pakistan. Tropical Animal Health and Production. 2015. DOI: 10.1007/s11250-015-0844-1

[117] Coppola S, Parente E, Dumontet S, La Peccerella A: The microflora ofnatural whey cultures utilized as starters in the manufacture of mozzarella cheese from water-buffalo milk. Le Lait 1988;68:295-310

[118] Ameni G, Aseffa A, Engers H, Young D, Gordon S, Hewinson G, Vordermeier M. High prevalence and increased severity of pathology of bovine tuberculosis in Holsteins compared to zebu breeds under field cattle husbandry in central Ethiopia. Clinical and Vaccine Immunology. 2007;14:1356-1361 
[119] Thakur A, Sharma M, Katoch VC, Dhar P, Katoch RC. A study on the prevalence of bovine tuberculosis in farmed dairy cattle in Himachal Pradesh. Veterinary World. 2010;3:409-414

[120] Innes EA, Panton WRM, Marks J, Trees AJ, Holmdahl OJM, et al. Interferon gamma inhibits the intracellular multiplication of Neospora caninum, as shown by incorporation of 3H uracil. Journal of Comparative Pathology. 1995;113:95-100

[121] Ifrahim M. Epidemiological studies on tuberculosis in cattle and buffalo population in villages around Faisalabad. M.Sc. (Hons.) Thesis Department of Veterinary Microbiology, University of Agriculture Faisalabad Pakistan; 2001

[122] Javed MT, Usman M, Irfan M, Cagiola M. A study on tuberculosis in buffaloes: Some epidemiological aspects, along with haematological and serum protein changes. Veterinarski Arhiv. 2006;76:193-206

[123] OIE. Bovine tuberculosis. In: Manual of Diagnostic Tests and Vaccines for Terrestrial Animals. 2009. Chapter 2.4.7.16 p.http://www.oie.int/en/international-standard-setting/ terrestrial-manual/access-online

[124] Seleem MN, Boyle SM, Sriranganathan N. Brucellosis: A re-emerging zoonosis. Veterinary Microbiology. 2010;140(3-4):392-398

[125] Marassi CD, Almeida C, Pinheiro S, Vasconcellos S, Lilenbaum W. The use of MPB70ELISA for the diagnosis of caprine tuberculosis in Brazil. Veterinary Research Communications. 2009;33:937-943

[126] Fitzgerald SD, Kaneene JB. Wildlife reservoirs of bovine tuberculosis worldwide: Hosts, pathology, surveillance, and control. Veterinary Pathology. 2012;50(3):488-499

[127] Cross PC, Getz WM. Assesing vaccination as a control strategy in an on going epidemic: Bovine tuberculosis in African buffalo. Ecological Modelling. 2006;196(3-4):494-504

[128] Amanfu W. The situation of tuberculosis and tuberculosis control in animals of economic interest. Tuberculosis. 2006;86:330-335

[129] de la Rua-Domenech R. Human Mycobacterium bovis infection in the United Kingdom: Incidence, risks, control measures and review of the zoonotic aspects of bovine tuberculosis. Tuberculosis (Edinburgh, Scotland). 2006;86:77-109

[130] Humblet MF, Boschiroli ML, Saegerman C. Classification of worldwide bovine tuberculosis risk factors in cattle: A stratified approach. Veterinary Research. 2009;40:24-27

[131] Dietzgen RG, Kuzmin IV. Rhabdoviridae. In: King AMQ et al., editors. Virus Taxonomy, 9th Report of the ICTV. Elsevier; 2011. pp. 654-681

[132] Hsieh YC, Chen SH, Chou CC, Hsiao HW, Chen SZ, Lee YF, Liu HJ. Bovine ephemeral fever in Taiwan (2001-2002). The Journal of Veterinary Medical Science. 2005;67:411-416

[133] Walker PJ. Bovine ephemeral fever in Australia and the world. Current Topics in Microbiology and Immunology. 2005;292:57-80 
[134] Yeruham I, Sharir B, Yadin H, Tiomkin D, Chai D. Bovine ephemeral fever in beef cattle herds in the Jordan Valley, Israel. The Veterinary Record. 2003;152:86-88

[135] Nandi S, Negi BS. Bovine ephemeral fever: A review. Comparative Immunology, Microbiology \& Infectious Diseases. 1999;22(2):81-91

[136] Bai WB, Jiang CL, Davis SS. Preliminary observations on the epidemiology of bovine ephemeral fever in China. Tropical Animal Health and Production. 1991;23:22-26. Bai WB. Epidemiology and control of bovine ephemeral fever in China, bovine ephemeral fever and related rhabdoviruses. In: St. George TD, Uren MF, Young PL, Hoffmann D (Eds.), ACIAR Proceedings No. 44. Australian Centre for International Agricultural Research, Canberra; 1993. pp. 20-22

[137] Cybinski DH, Walker PJ, Byrne KA, Zakrzewski H. Mapping of antigenic sites on the bovine ephemeral fever virus glycoprotein using monoclonal antibodies. The Journal of General Virology. 1990;71:2065-2072

[138] Davis SS, Gibson DS, Clark R. The effect of bovine ephemeral fever on milk production. Australian Veterinary Journal. 1984;61:128

[139] St. George TD. The epidemiology of bovine ephemeral fever in Australia and its economic effect. In: St George TD, Kay BH, Blok J, editors. Proceedings of the 4th Symposium on Arbovirus Research in Australia, Brisbane, May 1986. CSIRO-QIMR. 1986. pp. 281-289

[140] Balasubramaniam S, Kumar S, Sharma A, Mitra A. Microsatellite (GT)n polymorphism at 3'UTR of SLC!!A! Influences the expression of brucella LPS induced MCP1 mRNA in buffalo peripheral blood mononuclear cells. Veterinary Immunology and Immunopathology. 2013;152(2013):295-302

[141] Aziz-Boaron O, Gleser D, Yadin H, Gelman B, Kedmi M, Galon N, Klement E. The protective effectiveness of an inactivated bovine ephemeral fever virus vaccine. Veterinary Microbiology. 2014;173:1-8

[142] Walker PJ. Bovine ephemeral fever: Cyclic resurgence of a climatesensitive vectorborne disease. Microbiology Australia. 2013:41-42

[143] Zhang M, Ge J, Wen Z, Chen W, Wang X, Liu R, Bu Z. Characterization of a recombinant Newcastle disease virus expressing the glycoprotein of bovine ephemeral fever virus. Archives of Virology. 2017;162:359-367

[144] Zheng FY, Qiu CH. Phylogenetic relationships of the glycoprotein gene of bovine ephemeral fever virus isolated from mainland China, Taiwan, Japan, Turkey, Israel and Australia. Virology Journal. 2012;9:268

[145] Tonbak S, Berber E, Yoruk MD, Azkur AK, Pestil Z, Bulut H. A largescale outbreak of bovine ephemeral fever in Turkey, 2012. The Journal of Veterinary Medical Science. 2013;75:1511-1514

[146] Radostitis OM, Gay CG, Hinchcliff KW, Constable PD. Veterinary Medicine. 10th ed. Philadelphia: Sounders/Elsevier; 2007 
[147] Jakobsson S. Diagnosis and molecular epidemiology of bovine rotavirus and coronavirus in Brazil. Examensarbete. 2013;2013:22

[148] Kapikian AZ, Chanock RM. Rotaviruses. In: Fields BN, Knipe DM, editors. Field's Virology. 2nd ed. Vol. 2. New York: Raven Press; 1990. pp. 1353-1403

[149] Greenberg H, Mcauliffe V, Valdesuso J, Wyatt R, Flores J, Kalica AR, Hoshino Y, Singh N. Serological analysis of the subgroup protein of rotavirus using monoclonal antibodies. Infection and Immunity. 1983;39:91-99

[150] Collins PJ, Mulherin E, Cashman O, Lennon G, Gunn L, O'Shea H, Fanning S. Detection and characterisation of bovine rotavirus in Ireland from 2006-2008. Irish Veterinary Journal. 2014;67:13

[151] Casaubon J, Vogt H, Stalder H, Hug C, Ryser-Degiorgis MP. Bovine viral diarrhea virus in free-ranging wild ruminants in Switzerland: Low prevalence of infection despite regular interactions with domestic livestock. BMC Veterinary Research. 2012;8:204

[152] Pisanelli G, Martella V, Pagnini U, Martino LD, Lorusso E, Iovane G, Buonavoglia C. Distribution of G (VP7) and P (VP4) genotypes in buffalo group a rotaviruses isolated in southern Italy. Veterinary Microbiology. 2005;110:1-6

[153] Chigor VN, Sibanda T, Okoh AI. Assessment of the risks for human health of adenoviruses, hepatitis a virus, rotaviruses and enteroviruses in the Buffalo River and three source water dams in the eastern cape. Food and Environmental Virology. 2014 Jun;6(2):87-98

[154] Sravani GVD, Kaur G, Chandra M, Dwivedi PN. P and G genotyping of bovine rotavirus and its prevalence in neonatal calves. Veterinarski Arhiv. 2014;84(5):475-484

[155] Medici MC, Tummolo F, Bonica MB, Heylen E, Zeller M, Calderaro A, Matthijnssens J. Genetic diversity in three bovine-like human G8P[14] and G10P[14] rotaviruses suggests independent interspecies transmission events. Journal of General Virology. 2015;96:1161-1168

[156] Matthijnssens J, Bilcke J, Ciarlet M, Martella V, Bányai K, Rahman M, Zeller M, Beutels P, Van Damme P, Van Ranst M. Rotavirus disease and vaccination: Impact on genotype diversity. Future Microbiology. 2009;4:1303-1316

[157] The Cattle Site. Cattle Health, Welfare and Diseases News. England: 5m Publishing, Benchmark House; 2014. Available online at: http://www.thecattlesite.com/diseaseinfo/234/

[158] Martucciello A, De Mia GM, Giammarioli M, De Donato I, Iovane G, Galiero G. Detection of bovine viral diarrhea virus from three water buffalo fetuses (Bubalus bubalis) in southern Italy. Journal of Veterinary Diagnostic Investigation. 2009;21(1):137-140

[159] Nettleton PF. Pestivirus infections in ruminants other than cattle. Revue Scientifique et Technique. 1990;9:131-150

[160] Bauermanna FV, Falkenbergc SM, Decarod N, Floresb EF, Ridpatha JF. Experimental infection of calves, sheep, goats and pigs with HoBi-like viruses by direct inoculation or exposure to persistently infected calves. Veterinary Microbiology.2015;181(2015):289-293 
[161] Pecora A, Pérez-Aguirreburualde MS, Malacari DA, Zabal O, Sala JM, Konrad JL, Caspe SG, Bauermann F, Ridpath J, Dus Santos MJ. Serologic evidence of HoBi-like virus circulation in Argentinean water buffalo. Journal of Veterinary Diagnostic Investigation. 2017;1:1040638717720246

[162] Baker JC. The clinical manifestations of bovine viral diarrhea infection. The Veterinary Clinics of North America. Food Animal Practice. 1995;11:425-434

[163] Tse H, Chan WM, Tsoi HW, Fan RY, Lau CC, Lau SK, Woo PC, Yuen KY. Rediscovery and genomic characterization of bovine astroviruses. The Journal of General Virology. 2011;92:1888-1898

[164] Yeşilbağ K, Alpay G, Becher P. Variability and global distribution of subgenotypes of bovine viral diarrhea virus. Virus. 2017;9:128

[165] De Benedictis P, Schultz-Cherry S, Burnham A, Cattoli G. Astrovirus infections in humans and animals - Molecular biology, genetic diversity, and interspecies transmissions. Infection, Genetics and Evolution. 2011;11:1529-1544

[166] Fulton RW, Briggs RE, Ridpath JF, Saliki JF, Confer AW, Payton ME, Duff GC, Step DL, Walker DA. Transmission of bovine viral diarrhea virus $1 \mathrm{~b}$ to susceptible and vaccinated calves by exposure to persistently infected calves. Canadian Journal of Veterinary Research. 2005;69(3):161-169

[167] Atreya CD. Major foodborne illness causing viruses and current status of vaccines against the diseases. Foodborne Pathogens and Disease. 2004;1:89-96

[168] Coura JR, Borges-Pereira. Chagas disease: 100 years after its discovery. A systemic review. Acta Tropica. 2010;115(1-2):5-13

[169] Desquenses M, Dargantes A, Lai D-H, Lun Z-R, Holzmuller P, Jittapalapong S. Trypanosoma evansi and Surra: A review and perspective on transmission, epidemiology and control, impact, and zoonotic aspects. BioMed Research International. 2013;2013

[170] Desquenses M, Holzmuller P, Lai D-H, Dargantes A, and Jittapalapong S. 2013. Trypanosoma evansi and Surra: A review and perspective origin, history, distribution, taxonomy, morphology, hosts, and pathogenic effects. BioMed Research International, vol. 2013

[171] Borst P, Fase-Fowler F, Gibson WC. Kinetoplast DNA of Trypanosoma evansi. Molecular and Biochemical Parasitology. 1987;23(1):31-38

[172] Lai DH, Hashimi H, Lun ZR, Ayala FJ, Lukes J (2008). Adaptations of Trypanosoma brucei to gradual loss of kinetoplast DNA: Trypanosoma equiperdum and Trypanosoma evansi are petite mutants of T. brucei. Proceedings of the National Academy of Sciences of the United States of America, vol. 105, no. 6, pp. 1999-2004

[173] Lun ZR, Desser SS. Is the broad range of hosts and geographical distribution of Trypanosoma evansi attributable to the loss of maxicircle kinetoplast DNA? Parasitology Today. 1995;11(4):131-133 
[174] Hoare CA. The Trypanosomes of Mammals: A Zoological Monograph. Oxford, UK: Blackwell Scientific Publications; 1972

[175] Reid SA, Dargantes AP, Husein A, and Constantine CC. Geographic variation in the pathogenicity of Trypanosmoma evansi. Proceedings of the Annual Scientific Meeting of Australian Society for Parasitology, Hobart, Australia; 2002

[176] Garcia H, Garcia ME, Perez H, Mendoza-Leon A. The detection and PCR-based characterization of the parasites causing tryponosomiasis in water buffalo herds in Venezuela. Annals of Tropical Medicine and Hygiene. 75(3):471-473

[177] Kageruka P, Mortelmans J. Isolement de Trypanosoma evansi Steel 1885 d'un cabiai (Hydrochoerus hydrochaeris Lin) importee n Belgique et etude preliminaire de sa virulence. Annales de la Société Belge de Médecine Tropicale. 1971;51:709-716

[178] Payne RC, Sukanto IP, Partuotomo S, Polytedi F. Experimental infection of Freisian Holstein calves with an Indonesian isolate of Trypanosoma evansi. Tropical Medicine and Parasitology. 1992;43(2):115-117

[179] Indrakamgang P. Trypanosoma evansi infection in livestock in Thailand. Journal of Protozoological Research. 1998;8:153-161

[180] Sudarto MW, Tabel H, Haines DM. Immunohistochemical demonstration of Trypanosoma evansi in tissues of experimentally infected rats and a naturally infected water buffalo (Bubalis bubalis). The Journal of Parasitology. 1990;76(2):162-167

[181] Lang P, PS, PA. Studies on incidence and control of trypanosomiasis in buffaloes caused by Trypanosoma evansi Steel 1885 in North Vietnam. Proceedings of the Buffalo Workshop. Vol. 1, Hanoi, Vietnam, December 2001; 2001. pp. 1-8

[182] Chobjit S, Kheowsri S, Rodtian P, Jongchansittoe P, Nuangmek A. An outbreak of bovine surra in Maehongsorn Province. Chiang Mai Veterinary Journal. 2006;4(2):127-136

[183] Abo-Shehada MN, Anshassi H, Mustafa G, Amr Z. Prevalence of Surra among camels and horses in Jordan. Preventive Veterinary Medicine. 1999;38(4):289-293

[184] Laohasinnarong D, Goto Y, Asada M, Nakao R, Hayashida K, Kajino K, Kawazu S, Sugimoto C, Inoue N, Namangala B. Studies of trypanosomiasis in the Luangwa valley, north-eastern Zambia. Parasites \& Vectors. 2015;8:497. DOI: 10.1186/s13071-015-1112-y

[185] Rodriguez Diego J, Abreu JR, Perez E, Roque E, Cartas O. Presence of cryptosporidium in buffaloes (Bubalus bubalis) in Cuba. Revista de Salud Animal. 1991;13:78-80

[186] Nguyen QD, Nguyen TT, Pham QP, Le NM, Nguyen GT, Inoue N. Seroprevalence of Trypanosoma evansi infection in water buffaloes from the mountainous region of North Vietnam and effectiveness of trypanocidal drug treatment. The Journal of Veterinary Medical Science. 2013;75(9):1267-1269

[187] Nguyen TT, Motsiri MS, Taioe MO, Mtshali MS, Goto Y, Kawazu S, Thekisoe OM, Inoue N. Application of crude and recombinant ELISAs and immunochromatographic test for serodiagnosis of animal trypanosomosis in the Umkhanyakude district of 
KwaZulu-Natal province, South Africa. The Journal of Veterinary Medical Science. 2015;77(2):217-220. DOI: 10.1292/jvms.14-0330

[188] Kocher A, Desquesnes M, Kamyingkird K, Yangtara S, Leboucher E, Rodtian P, Dargantes A, Jittapalapong S. Evaluation of an indirect-ELISA for Trypanosoma evansi infection (Surra) in buffaloes and its application to a Serologival survey in Thailand. BioMed Research International. 2015;205:361037. DOI: 10.1155/2015/361037

[189] Laohasinnarong D, Thekisoe OM, Malele I, Namangala B, Ishii A, Goto Y, Kawazu S, Sugmoto $\mathrm{C}$, Inoue N. Prevalence of Trypanosoma sp in cattle from Tanzania estimated by conventional PCR and loop-mediated isothermal amplification (LAMP). Parasitology Research. 2011;109(6):9. DOI: 10.1007/s00436-011-2513-2

[190] Musinguzi SP, Suganuma K, Asama M, Laohasinnarong D, Sivakumar T, Yokoyama N, Namangala B, Sugimoto C, Suzuki Y, Xuan X, Inoue N. A PCR-based survey of animal African trypanosomiasis and selected piroplasm parasites of cattle and goats in Zambia. The Journal of Veterinary Medical Science. 2017;78(12):1819-1824. DOI: 10.1292/jvms.16-0240

[191] Hilali M, Abdel-Gawad A, Nassar A, Abdel-Wahab A. Hematological and biochemical changes in water buffalo calves (Bubalis bubalis) infected with Trypanosoma evansi. Veterinary Parasitology. 2006;139(1-3):237-243

[192] Onah DN, Hopkins J, Luckins AG. Effects of the depletion of CD8+ T cells and monocytes on the proliferative responses of peripheral blood leucocytes from Trypanosoma evansi-infected sheep. Veterinary Parasitology. 2000;92(1):25-35

[193] Dia ML, Desquenses M, Elsen P, Lancelot R, Acapovi G. Evaluation of new trap for tabanids and stomoxines. Bulletin de la Societe Royale Belge d'Entomologie. 2004;140:64-73

[194] Dargantes AP, Mercado RT, Dobson RJ, Reid SA. Estimating the impact of Trypanosoma evansi infection (surra) on buffalo population dynamics in southern Philippines using data from cross-sectional surveys. International Journal for Parasitology. 2009; 39(10):1109-1114

[195] Reichel MP, Alejandra Ayanegui-Alcérreca M, Gondim LF, Ellis JT. What is the global economic impact of Neospora caninum in cattle - the billion dollar question. International Journal for Parasitology. 2013;43:133-142

[196] Moore DP, Konrad JL, San Martino S, Reichel MP, Cano DB, Mendez S, Spath EJ, Odeon AC, Crudeli G, Campero CM. Neospora caninum serostatus is affected by age and species variables in cohabiting water buffaloes and beef cattle. Veterinary Parasitology. 2014;203:259-263

[197] Reichel MP, MacAllister MM, Nasir A, Moore DP. A review of Neospora caninum in water buffalo (Bubalis bubalis). Veterinary Parasitology. 2015. Accepted Manuscript

[198] Rodrigues AA, Gennari SM, Paula VS, Aguiar DM, Fujii TU, Starke-Buzeti W, Machado RZ, Dubey JP. Serological responses to Neospora caninum in experimentally and naturally infected water buffaloes (Bubalus bubalis). Veterinary Parasitology. 2005;129:21-24 
[199] Hunter PR, Thompson RC. The zoonotic transmission of giardia and cryptosporidium. International Journal for Parasitology. 2005;35:1181-1190

[200] Konrad JL, Moore DP, Crudeli G, Caspe SG, Cano DB, Leunda MR, Lischinsky L, Regidor-Cerrillo J, Odeon AC, Ortega-Mora LM, Echaide I, Campero CM. Experimental inoculation of Neospora caninum in pregnant water buffalo. Veterinary Parasitology. 2012;187:72-78

[201] Chryssafidis A, Soares R, Rodrigues A, Carvalho N, Gennari S. Evidence of congenital transmission of Neospora caninum in naturally infected water buffalo (Bubalus bubalis) fetus from Brazil. Parasitology Research. 2011;108:741-743

[202] Chryssafidis AL, Canton G, Chianini F, Innes EA, Madureira EH, Soares RM, Gennari SM. Abortion and foetal lesions induced by Neospora caninum in experimentally infected water buffalos (Bubalus bubalis). Parasitology Research. 2015;114:193-199

[203] Innes EA, Andrianarivo AG, Bj€orkman C, Williams DJL, Conrad PA. Immune responses to Neospora caninum and prospects for vaccination. Trends in Parasitology. 2002;18:497-504

[204] Maley SW, Buxton D, Macaldowie CN, Anderson IE, Wright SE, et al. Characterization of the immune response in the placenta of cattle experimentally infected with Neospora caninum in early gestation. Journal of Comparative Pathology. 2006;135:130-141

[205] Huong LTT, Ljunsgrtröm BL, Uggla A, Björkman C. Prevalence of antibodies to Neospora caninum and toxoplasma gondii in cattle and water buffaloes in southern Vietnam. Veterinary Parasitology. 1998;75:53-57

[206] Gondim LFP, Souza RM, Guimarães JE, Almeida MAO. Frequência de anticorpos contra Neospora caninum em búfalos criados no Estado da Bahia. Proceedings of the Seminário Brasileiro de Parasitologia Veterinária. 1999;11:227

[207] Guarino A, Fusco G, Savini G, Di Francesco G, Cringoli G. Neosporosis in water buffalo (Bubalus bubalis) in southern Italy. Veterinary Parasitology. 2000;91:15-21

[208] Souza LM, Nascimento AA, Furuta PI, Basso LMS, Silveira DM, Costa AJ. Detecção de anticorpos contra Neospora caninum em soros de bubalinos (Bubalus bubalis) no Estado de São Paulo, Brasil. Revista Semina. 2001;22(1):39-48

[209] Fujii TU, Kasai N, Nishi SM, Dubey JP, Gennari SM. Seroprevalence of Neospora caninum in female water buffalos (Bubalus bubalis) from the southeastern region of Brazil. Veterinary Parasitology. 2001;99:331-334

[210] Gennari SM, Rodrigues AA, Viana RB, Cardoso EC. Occurrence of anti-Neospora caninum antibodies in water buffaloes (Bubalus bubalis) from the northern region of Brazil. Veterinary Parasitology. 2005;134(1-2):169-171

[211] Vogel FSF, Arenhart S, Bauermann FV. Anticorpos anti-Neospora caninum em bovinos, ovinos e bubalinos no Estado do Rio Grande do Sul. Ciência Rural. 2006;36(6):1948-1951 
[212] Yu J, Xia Z, Liu Q, Liu J, Ding J, Zhang W. Seroepidemiology of Neospora caninum and toxoplasma gondii in cattle and water buffaloes (Bubalus bubalis) in the People's republic of China. Veterinary Parasitology. 2007;143(3):79-85

[213] Campero CM, Pérez A, Moore DP, Crudeli G, Benitez D, Draghi MG, Cano D, Konrad JL, Odeón AC. Occurrence of antibodies against Neospora caninum in water buffalos (Bubalus bubalis) on four ranches in Corrientes province, Argentina. Veterinary Parasitology. 2007;150(1-2):155-158

[214] Hajikolaei MRH, Goraninejad S, Hamidinejat H, Ghorbanpour M, Paryab R. Occurrence of Neospora caninum antibodies in water buffaloes (Bubalus bulalis) from the south-western region of Iran. Bulletin of the Veterinary Institute in Pulawy. 2007;51:233-235

[215] Konnai S, Mingala CN, Sato M, Abes NS, Venturina FA, Gutierrez CA, Sano T, Omata Y, Cruz LC, Onuma M, Ohashi K. A survey of abortifacient infectious agents in livestock in Luzon, the Philippines, with emphasis on the situation in a cattle herd with abortion problems. Acta Tropica. 2008;105:269-273

[216] Abes NS, Divina BP. Seroprevalence of Neospora caninum in Bulgarian Murrah buffaloes and its detection in domestic dogs from buffalo dairy herds in Nueva Ecija, Philippines. Philippine Journal of Veterinary Medicine. 2008;45:30-38

[217] Silva SP, Mota RA, Faria EB, Fernandes EFTS, Neto OLS, Albuquerque PPF, Dilmas HLT. Occurrence of IgG antibodies anti-Neospora caninum and toxoplasma gondii in female water buffalos (Bubalus bubalis) raised in the Brazilian state of Pará. Pesquisa Veterinaria Brasileira. 2010;30(5):443-446

[218] Nasir A, Ashraf M, Khan MS, Yaqub T, Javeed A, Avais M, Akhtar F. Seroprevalence of Neospora caninum in dairy buffaloes in Lahore District, Pakistan. The Journal of Parasitology. 2011;97:541-543

[219] Auriemma C, Lucibelli MG, Borriello G, De Carlo E, Martucciello A, Schiavo L, Gallo A, Bove F, Corrado F, Girardi S, Amoroso MG, Degli Uberti B, Galiero G. PCR detection of Neospora caninum in water buffalo foetal tissues. Acta Parasitologica. 2014;59:1-4

[220] Hamidinejat H, Seifi Abad Shapouri MR, Namavari MM, Shayan P, Kefayat M. Development of an indirect ELISA using different fragments of recombinant Ncgra7 for detection of Neospora caninum infection in cattle and water buffalo. Iranian Journal of Parasitology. 2015;10:69-77

[221] Shaapan RM. The common zoonotic protozoal disease causing abortion. Indian Society for Parasitology. 2015. DOI: 10.1007/s12639-015-0661-5

[222] Cama V, Bern C, Roberts J, Cabrera L, Sterling C, Ortega Y. Cryptosporidium species and subtypes and clinical manifestations in children, Peru. Emerging Infectious Diseases. 2008;14(7)

[223] Chalmers RM, Davies AP. Minireview: Clinical cryptosporidiosis. Experimental Parasitology. 2010;124:138-146 
[224] Xiao L, Morgan UM, Limor J, Escalante A, Arrowood M, Shulaw W. Genetic diversity within Cryptosporidium parvum and related species of cryptosporidium. Applied and Environmental Microbiology. 1999;65:3386-3391

[225] Thompson RC, Armson A, Ryan UM. Cryptosporidium: From Molecules to Disease. London: Elsevier, Amsterdam; 2003

[226] Xiao L. Molecular epidemiology of cryptosporidiosis: An update. Experimental Parasitology. 2010;124:80-89

[227] Feng Y, Raj Karna S, Dearen TK, Singh DK, Adhikari LN, Shrestha A, Xiao L. Common occurrence of a unique Cryptosporidium ryanae variant in zebu cattle and water buffaloes in the buffer zone of the Chitwan National Park, Nepal. Veterinary Parasitology. 2012;185:309-314

[228] Robertson LJ, Campbell AT, Smith HV. Survival of Cryptosporidium parvum oocysts under various environmental pressures. Applied and Environmental Microbiology. 1992; 58:3494-3500

[229] Mahfouz ME, Mira N, Amer S. Prevelance and genotyping of Cryptosporidium spp. in farm animal in Egpyt. Journal of Veterinary Science. 2014;76(12):1596-1575

[230] Abou-Eisha A. Cryptosporidial infection in man and farmanimals in Ismailia governorate. Veterinary Medical Journal - Giza. 1994;42:107-111

[231] Amer S, Zidan S, Feng Y, Adamu H, Li N, Xiao L. Identity and public health potential of Cryptosporidium spp. in water buffalo calves in Egypt. Veterinary Parasitology. 2013; 191:123-127

[232] Saralli G, Condoleo RU, Centra A, Scissione U, Bernardi C. Diffusione di Cryptosporidium parvum in bufali allevati in provincia di Latina. Atti I Congresso Nazionale sull_Allevamento del Bufalo; 2001. pp. 420-423

[233] Gomez-Couso H, McLauchlin J, Ares-Mazas E. Characterisation of a cryptosporidium isolate from water buffalo (Bubalus bubalis) by sequencing of a fragment of the cryptosporidium oocyst wall protein gene (COWP). Veterinary Parasitology. 2005;131:139-144

[234] Rinaldi L, Condoleo RU, Condoleo R, Saralli G, Bruni G, Cringoli G. Cryptosporidium and giardia in water buffaloes (Bubalus bubalis) of the Italian Mediterranean bred. Veterinary Research Communications. 2007;31(Suppl. 1):253-255

[235] Shoukry NM, Dawoud HA, Haridy FM. Studies on zoonotic Cryptosporidium parvum in Ismailia governorate, Egypt. Journal of the Egyptian Society of Parasitology. 2009;39:479-488

[236] Nasir A, Avais M, Khan MS, Ahmad N. Prevalence of Cryptosporidium paroum infection in Lahore (Pakistan) and its association with diarrhea in dairy calves. International Journal of Agriculture and Biology. 2009;11:221-224

[237] Bhat SA, Juyal PD, Singla LD. Prevalence of cryptosporidiosis in neonatal buffalo calves in Ludhiana District of Punjab, India. Asian Journal of Animal and Veterinary. 2012;7:512-520 
[238] Abeywardena H, Jex AR, von Samson-Himmelstjerna G, Haydon SR, Stevens MA, Gasser RB. First molecular characterization of Crypstosporidium and giardia from Bubalus bubalis (water buffalo) in Victoria, Australia. Infection, Genetics and Evolution. 2013;20(2013):96-102

[239] Abu Samra N, Jori F, Xiao L, Rikhotso O, Thompson PN. Molecular characterization of cryptosporidium species at the wildlife/livestock interface of the Kruger National Park, South Africa. Comparative Immunology, Microbiology and Infectious Diseases. 2013;36(3):295-302

[240] Helmy YA, Krücken J, Nöckler K, Von Samson-Himmelstjerna G, Zessin KH. Molecular epidemiology of Cryptosporidium in livestock animals and humans in the Ismailia province of Egypt. Veterinary Parasitology. 2013;193(1-3):15-24

[241] Galiero G, Consalvo F, Carullo M. La criptosporidiosicnei vitelli bufalini: un aggiornamento. Selezione Veterinaria. 1994;35:449-453

[242] Ma J, Li P, Zhao X, Xu H, Wu W, Wang Y, Guo Y, Wang L, Feng Y, Xiao L. Occurrence and molecular characterization of Cryptosporidium spp. and Enterocytozoon bieneusi in dairy cattle, beef cattle and water buffaloes in China. Veterinary Parasitology. 2015; 207(3-4):220-227

[243] Aquino MCC, Widmer G, Zucatto AS, Viol MA, Inacio SV, Nakamura AA, Coelho WMD, Perri SHV, Meireles MV, Bresciani KDS. First molecular characterization of Cryptosporidium spp. infecting buffalo calves in Brazil. Journal of Eukaryotic Microbiology;62(5):657-661. DOI: 10.1111/jeu/12223

[244] Zahedi A, Phasey J, Boland T, Ryan U. First report of cryptosporidium species in farmed and wild buffalo from northern territory, Australia. Parasitology Research. 2016. DOI: 10.0007/s00436-016-4901-0

[245] Fayer R, Santin M, Trout JM. Prevalence of Cryptosporidium species and genotypes in mature dairy cattleon farms in eastern United States compared with younger cattle from the same locations. Veterinary Parasitology. 2007;145:260-266

[246] Jex AR, Chalmers RM, Smith HV, Widmer G, McDonald V. B., gasser, R.B., cryptosporidiosis. In: Palmer SR, Soulsby EJL, Torgerson PR, Brown DWG, editors. Oxford Textbook of Zoonoses. New York: Oxford University Press Inc.; 2011 (Chapter 46)

[247] Thompson RC, Palmer CS, O'Handley R. The public health and clinical significance of giardia and cryptosporidium in domestic animals. Veterinary Journal. 2008;177:18-25

[248] Thompson RC, Monis PT. Variation in giardia: Implications for taxonomy and epidemiology. Advances in Parasitology. 2004;58:69-137

[249] Betancourt WQ, Rose JB. Drinking water treatment processes for removal of cryptosporidium and giardia. Veterinary Parasitology. 2004;126:219-234

[250] Carpenter C, Fayer R, Trout J, Beach MJ. Chlorine disinfection of recreational water for Cryptosporidium parvum. Emerging Infectious Diseases. 1999;5:579-584 
[251] Korich DG, Mead JR, Madore MS, Sinclair NA, Sterling CR. Effects of ozone, chlorine dioxide, chlorine, and monochloramine on Cryptosporidium parvum oocyst viability. Applied and Environmental Microbiology. 1990;56:1423-1428

[252] Homan WL, Mank TG. Human giardiasis: Genotype linked differences in clinical symptomatology. International Journal for Parasitology. 2001;31:822-826

[253] O'Donoghue PJ. Cryptosporidium and cryptosporidiosis in man and animals. International Journal for Parasitology. 1995;25:139-195

[254] Hunter PR, Nichols G. Epidemiology and clinical features of cryptosporidium infection in immunocompromised patients. Clinical Microbiology Reviews. 2002;15:145-154

[255] Petri WA, Miller M, Binder HJ, Levine MM, Dillingham R, Guerrant RL. Enteric infections, diarrhea, and their impact on function and development. The Journal of Clinical Investigation. 2008;118:1277-1290

[256] Smith HV, Cacciò SM, Tait A, McLauchlin J, Thompson RC. Tools for investigating the environmental transmission of cryptosporidium and giardia infections in humans. Trends in Parasitology. 2006;22:160-167

[257] Foronda P, Bargues MD, Abreu-Acosta N, Periago MV, Valero MA, Valladares B, MasComa S. Identification of genotypes of Giardia Intestinalis of human isolates in Egypt. Parasitology Research. 2008;103:1177-1181

[258] Cacciò SM, Thompson RC, McLauchlin J, Smith HV. Unravelling cryptosporidium and giardia epidemiology. Trends in Parasitology. 2005;21:430-437

[259] Xiao L, Fayer R. Molecular characterisation of species and genotypes of cryptosporidium and giardia and assessment of zoonotic transmission. International Journal for Parasitology. 2008;38:1239-1255

[260] Xiao L, Fayer R, Ryan UM, Upton SJ. Cryptosporidium taxonomy: Recent advances and implications for public health. Clinical Microbiology Reviews. 2004;17:72-97

[261] Budu-Amoako E, Greenwood SJ, Dixon BR, Barkema HW, McClure JT. Foodborne illness associated with cryptosporidium and giardia from livestock. Journal of Food Protection. 2011;74:1944-1955

[262] Geurden T, Geldhof P, Levecke B, Martens C, Berkvens D, Casaert S, Vercruysse J, Claerebout E. Mixed giardia duodenalis assemblage a and $\mathrm{E}$ infections in calves. International Journal for Parasitology. 2008;38:259-264. Feng Y, Xiao L. Zoonotic potential and molecular epidemiology of Giardia species and giardiasis. Clinical Microbiology Reviews. 2011;24:110-140

[263] Santín M, Trout JM, Xiao L, Zhou L, Greiner E, Fayer R. Prevalence and age-related variation of crypto sporidium species and genotypes in dairy calves. Veterinary Parasitology. 2004;122:103-117

[264] Xiao L, Feng Y. Zoonotic cryptosporidiosis. FEMS Immunology and Medical Microbiology. 2008;52:309-323 
[265] Perera BMAO. Reproductive cycles of buffalo. Animal Reproduction Science. 2011;124: 194-199

[266] Kosek M, Alcantara C, Lima AA, Guerrant RL. Cryptosporidiosis: An update. The Lancet Infectious Diseases. 2001;1:262-269

[267] Jarvie BD, Trotz-Williams LA, McKnight DR, Leslie KE, Wallace MM, Todd CG, Sharpe $\mathrm{PH}$, Peregrine AS. Effect of halofuginone lactate on the occurrence of Cryptosporidium parvum and growth of neonatal dairy calves. Journal of Dairy Science. 2005;88:1801-1806

[268] Lefay D, Naciri M, Poirier P, Chermette R. Efficacy of halofuginone lactate in the prevention of cryptosporidiosis in suckling calves. The Veterinary Record. 2001;148:108-112

[269] Gordon CA, Acosta LP, Gobert GN, Jiz M, Olveda RM, Ross AG, Gray DJ, Williams GM, Harn D, Li Y, McManus DP. High prevalence of Schistosoma japonicum and Fasciola gigantica in bovines from Northern Samar, the Philippines. PLoS Neglected Tropical Diseases. 2015;9(2):1-13

[270] Jadhav UM, Singhvi R, Shah R. Prognostic implications of white cell differential count and white cell morphology in malaria. Journal of Postgraduate Medicine. 2003; 49:218-221

[271] Ravi Kanth Reddy P, Nagarjuna Reddy A, Raja Kishore K, Pratap Reddy V, Pandu Ranga Reddy P, Ramesh R, Singh S, Prathap B. Bovine Mycotoxicosis - a remarkable disease in Rice- growing areas of Indian subcontinent. IJSN. 2016;7(4):805-808

[272] Kumar M. Therapeutic management of Degnala disease in a buffalo calf: A case report. International Journal of Agricultural Sciences and Veterinary Medicine. 2016;2016(4)

[273] Dandapat P, Nanda PK, Bandyopadhyay S, Kaushal A, Sikdar A. Prevalence of Deg Nala disease in eastern India and its reproduction in buffaloes by feeding Fusarium oxysporum infested rice straw. Asian Pacific Journal of Tropical Medicine. 2011;(2011):54-57

[274] Karki K, Manandhar P, Koirala P, Manandhar S. Moldy rice straw poisoning in dairy cattle in Kathmandu Valley Nepal. Prime Journal of Microbiology Research (PJMR). 2012;3(1):170-104

[275] Kathiriya JB, Savaliya KB, Ahlawat AR, Godasara SN, Patel JS. A unique case of Deg Nala disease in Gir cow and its therapeutic management. International Journal of Current Microbiology and Applied Sciences. 2017;6(5):190-192

[276] Dhillon KS, Dhillon SK. Selenium toxicity in soil-plant-animal system- A case study. In Transactions 14th Inter. Congr. Congr. Soil Sci., Kyoto, Japan, IV; 1990. pp. 300-305

[277] Deore MD, Srivastava AK, Sharma SK. Effect of reduced glutathione treatment on selenosis, blood selenium concentration and glutathione peroxidase activity after repeated short-term selenium exposure in buffalo calves. Toxicology. 2005;213:169-174

[278] Arora SP, Prasad T, Chopra RC. Selenomethionine in the Ateioloy of Degnala Disease in Buffalo. On Line Published on January 21. 2012 
[279] Salib FA, Farghali HA. Epidemiological, therapeutic and surgical studies on tail necrosis in Egypt. International Journal of Veterinary Science. 2016;5(2):58-63

[280] Datt C, Kumar A, Prusty S, Kundu SS. Effect of supplementation of arsenic and Pentasulphate mixture in the diets of Murrah buffaloes given high level of selenium on blood selenium and erythrocyte glutathione peroxidase activity. The Journal of Animal and Plant Sciences. 2014;24(Suppl. 1):12-15

[281] Pilsner JR, Hall MN, Liu X, Ahsan H, Ilievski V, Slavkovich V, Levy D, Factor-Litvak P, Graziano JH, Gamble MV. Associations of plasma selenium with arsenic and genomic methylation of leukocyte DNA in Bangladesh. Environmental Health Perspectives. 2011;119:113-118

[282] Kalra DS, Bhatia KC. Degnala disease in buffaloes and cattle: Epidemiological investigations. Journal of Environmental Pathology, Toxicology and Oncology. 1990;10(3):132-135

[283] Soliman FM. Epidemiological review of human and animal fasciolosis in Egypt. The Journal of Infection in Developing Countries. 2008;2:182-189

[284] Centers for Disease Control and Prevention. Laboratory Identification of Parasites of Public Health Concern; 2010

[285] Khan MK, Sajid MS, Khan MN, Iqbal Z, Iqbal MU. Bovine fasciolosis: Prevalence, effects of treatment on productivity and cost benefit analysis in five districts of Punjab, Pakistan. Research in Veterinary Science. 2009;87:70-75

[286] Kaplan RM, Dame JB, Reddy GR, Courtney CH. A repetitive DNA probe for the sensitive detection of Fasciola hepatica infected snails. International Journal of Parasitology. 1995;25(5):601-610

[287] Adediran OA, Adebiyi AI, Uwalaka EC. Prevalence of Fasciola species in ruminants under extensive management system in Ibadan southwestern Nigeria. African Journal of Medicine and Medical Sciences. 2014;43(Suppl):137-141

[288] Ayaz S, Ullah R, AbdEl-Salam NM, Shams S, Niaz S. Fasciola hepatica in some buffaloes and cattle by PCR and microscopy. ScientificWorldJournal. 2014;2014:462084. DOI: $10.1155 / 2014 / 462084$

[289] Gordon CA, Acosta LP, Gray DJ, Olveda RM, Jarilla B, Gobert GN, Ross AG, McManus DP. High prevalence of Schistosoma Japonicum infectin in Carabao from Samar Province, the Philippines: Implications for transmission and control. PLoS Neglected Tropical Diseases. 2012;6(9):e1778. DOI: 10.1371/journal.pntd.0001778

[290] Mochankana ME, Robertson ID. A retrospective study of the prevalence of bovine fasciolosis at major abattoirs in Botswana. Onderstepoort Journal of Veterinary Research. 2016;83(1):a1015. DOI: 10.4102/ojvr.v83i1.1015

[291] Nguyen NT, LE TC, Vo MDC, Van Cao H, Nguyen LT, Ho KT, Nguyen QN, Tran VQ, Matsumoto Y. High prevalence of cattle fascioliasis in coastal areas of Thua Thien hue province, Vietnam. The Journal of Veterinary Medical Science. 2017;79(6):1035-1042. DOI: 10.1292/jvms.16-0331 
[292] Elshrawaym NT, Mahmoud WG. Prevalence of fascioliasis (liver flukes) infection in cattle and buffaloes slaughtered at the municipal abbattoir of el-Kharga, Egypt. Veterinary World. 2017;10(8):914-1017. DOI: 10.14202/vetworld. 2017.914-917

[293] Meeusen E, Lee CS, Rickard MD, Brandon MR. Cellular responses during liver fluke infection in sheep and its evasion by the parasite. Parasite Immunology. 1995;17:35-45

[294] Dixit AK, Pooja D, Sharma RL. Immunodiagnostic/protective role of Cathepsin L cysteine proteinases secreted by Fasciola sp. - A review. Veterinary Parasitology. 2008; 154:177-184

[295] Venturina VM, Alejandro MAF, Baltazar CP, Abes NS, Mingala CN. Evidence of Fasciola spp. resistance to albendazole, triclabendazole and bromofenofos in water buffaloes (Bubalus bubalis). Annals of Parasitology. 61(4):283-289

[296] Piedrafita D, Spithill TW, Smith RE, Raadsma HW. Improving animal and human health through understanding liver fluke immunology. Parasite Immunology. 2010;32:572-581

[297] Olveda DU, Li Y, Olveda RM, Lam AK, McManus DP, Chau TNP, Harn DA, Williams GM, Gray DJ, Ross AGP. Bilharzia in the Philippines: Past, present, and future. International Journal of Infectious Diseases. 2014;18:52-56

[298] Wu HW, Qin YF, Chu K, Meng R, Liu Y, McGarvey ST, Olveda R, Acosta L, Ji MJ, Fernandez T, Friedman JF, Kurtis JD. High prevalence of Schistosoma japonicum infection in water buffaloes in the Philippines assessed by real-time polymerase chain reaction. American Journal of Tropical Medicine and Hygiene. 2010;82(4):646-652

[299] Li YS, McManus DP, Lin DD, Williams GM, Harn DA, Ross AG, Feng Z, Gray DJ. The Schistosoma Japonicum self-cure phenomenon in water buffaloes: Potential impact on the control and elimination of schistosomiasis in China. International Journal for Parasitology. 2014;44:167-171

[300] Kobak P, Pilarczyk B. Prevalence of gastrointestinal parasites of water buffaloes raised in the Notecka Forest region (Poland). Bulletin of the Veterinary Institute in Pulawy. 2012;56:33-36

[301] Angeles JMM, Leonardo LR, Goto Y, Kirinoki M, Villacorte EA, Hakimi H, Moendeg KJ, Lee S, Rivera PT, Inoue N, Chigusa Y, Kawazu S. Water buffalo as sentinel animals for schistosomiasis surveillance. Bulletin of the World Health Organization. 2015; 93:511-512

[302] Martins G, Lilenbaum W. Control of bovine leptospirosis: Aspects for consideration in a tropical environment. Research in Veterinary Science. 2017;112:156-160

[303] Ayele WY, Neill SD, Zinsstag J, Weiss MG, Pavlik I. Bovine tuberculosis: An old disease but new threat to Africa. The International Journal of Tuberculosis and Lung Disease. 2004;8(8):924-937

[304] Frye G. Bovine tuberculosis eradication. In: Thoen CO, Steele JH, editors. Mycobacterium bovis Infection in Animals and Humans. Iowa, Iowa, USA: Iowa State University Press; 1994 
[305] Kahn CM. The Merck Vet Manual. 10th ed. White House Station, New Jersey, USA: Merck and Co., Inc; 2010. pp. 299-301

[306] Zarden CFO, Marassi CD, Oelemann W, Lilienbaum W. A complementary diagnosis of natuarally occurring tuberculosis in water buffaloes (Bubalus bubalis) in Rio de Janeiro using a MPB70-ELISA, Brazil. Tropical Animal Health and Production. 45:1203-1206. DOI: $10.1007 / \mathrm{s} 11250-012-0347-2$

[307] Choubisa SL, Jaroli VJ. Gastrointestinal parasitic infection in diverse species of domestic ruminants inhabiting tribal rural areas of southern Rajasthan, India. Journal of Parasitic Diseases. 2013;37(2):271-275

[308] Hossain MM, Paul S, Rahman MM, Hossain FMA, Hossain MT, Islam MR. Prevalence and economic significance of caprine fascioliasis at Sylhet district of Bangladesh. Pakistan Veterinary Journal. 2011;31(2):113-116

[309] Racioppi O, Moriena RA, Alvarez JD, Crudeli GA. Fasciola hepatica: New buffalo (Bubalus bubalis) parasitosis in the province of Corrientes, Argentina. Italian Journal of Animal Science. 2007;6(sup2):948-950

[310] Bhutto B, Arijo A, Phullan MS, Rind R. Prevalence of fascioliasis in buffaloes under different agro-climatic areas of Sindh Province of Pakistan. International Journal of Agriculture and Biology. 2012;14(2):241-245

[311] Copeman DB, Copland RS. Importance and potential impact of liver fluke in cattle and buffalo. http://aciar.gov.au/files/node/9010/MN133\%20part\% 202.pdf; 2008

[312] Liu Y, Li F, Liu W, Dai RS, Tan YM, He DS, Lin RQ, Zhu XQ. Prevalence of helminths in water buffaloes in Hunan Province, China. Tropical Animal Health and Production. 2009;41:543-546 